Portland State University

PDXScholar

Spring 6-20-2013

\title{
Understory Diversity and Succession on Coarse Woody Debris in a Coastal, Old-growth Forest, Oregon
}

Shannon Lee Mcdonald

Portland State University

Follow this and additional works at: https://pdxscholar.library.pdx.edu/open_access_etds

Part of the Other Forestry and Forest Sciences Commons, and the Physical and Environmental Geography Commons

Let us know how access to this document benefits you.

\section{Recommended Citation}

Mcdonald, Shannon Lee, "Understory Diversity and Succession on Coarse Woody Debris in a Coastal, Oldgrowth Forest, Oregon" (2013). Dissertations and Theses. Paper 1045.

https://doi.org/10.15760/etd.1045

This Thesis is brought to you for free and open access. It has been accepted for inclusion in Dissertations and Theses by an authorized administrator of PDXScholar. Please contact us if we can make this document more accessible: pdxscholar@pdx.edu. 


\title{
Understory Diversity and Succession on Coarse Woody Debris \\ in a Coastal, Old-growth Forest, Oregon
}

by

Shannon Lee McDonald

A thesis submitted in partial fulfillment of the requirements for the degree of

\author{
Master of Science \\ in \\ Geography
}

Thesis Committee:

Keith S. Hadley, Chair

Martin Lafrenz

Hunter Shobe

Portland State University

2013 
(C) 2013 Shannon Lee McDonald 
ABSTRACT

This research examines the relationship between understory plant diversity and logs in a Pacific Northwest (PNW) Sitka spruce (Picea sitchensis)-western hemlock (Tsuga heterophylla) old-growth, coastal forest. These forests are renowned for their high forest productivity, frequent wind storms, and slow log decomposition rates that produce unmatched accumulations of coarse woody debris (CWD) yet few studies have examined the relationship between CWD and understory vegetation ecology. My research addressed this topic by comparing understory plant census data between paired fallen log and forest floor sites $(n=20$ pairs). My objectives were to: 1) determine the influence of substrate type on community composition and diversity, and 2) examine successional pathways and species assemblage patterns on CWD in various stages of decomposition. To meet these objectives I employed non-metric multidimensional scaling (NMDS) ordinations and unsupervised cluster analyses to identify and compare community assemblages on both substrates. These methods revealed similar species diversity and evenness between log and forest floor sites with compositional differences within and between substrates corresponding to habitat availability for colonization and light and moisture gradients. 
My results also suggest understory successional pathways related to decay class and characterized by an initial abundance of bryophytes, forbs, and seedlings followed by woody shrubs. Understory communities developing on logs also experienced increasing diversity, evenness, and divergence from forest floor communities consistent with log decomposition. These results differ from findings for boreal forests that reveal increasing similarity between substrate communities with increasing decay class. Recommendations for future research include the employment of a more robust sample size and direct measurements of environmental variables. Additional comparator studies are also needed to confirm the effects of forest type and decomposition on the relationship between CWD and forest understory communities. This study demonstrates how fine-scale wind disturbance fosters biodiversity through the creation of CWD substrate. My results and future research are essential for the development of silvicultural models designed to promote biodiversity in PNW coastal forests. 


\section{ACKNOWLEDGEMENTS}

I thank my advisor, Keith Hadley, for his role in shaping my undergraduate and graduate education in Geography. I greatly appreciate his encouragement, commitment, and dedication to this thesis and my studies in general. I owe the successful completion of this research to his unlimited efforts in providing feedback, insight, and grammar corrections. It is an honor to be his final advisee at Portland State University.

I also thank my committee members and teachers, Martin Lafrenz and Hunter Shobe. I appreciate their patience during the completion of this thesis and their valuable perspectives on my research. My education was immeasurably shaped by their enthusiasm and knowledge.

Additional thanks goes to my friend and colleague Beth Bambrick. I greatly appreciate her role as a sounding board and technical advisor throughout the years. I am also grateful for the William A. Rockie Scholarships and the Price Research Grant I received from the Portland State University Geography Department. 


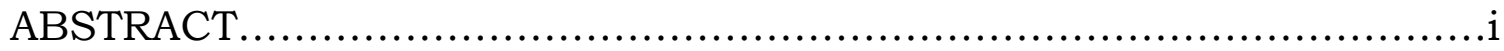

ACKNOWLEDGEMENTS ......................................................

LIST OF TABLES....................................................................

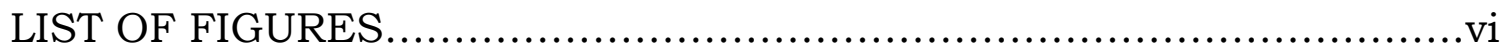

Chapter 1. INTRODUCTION ......................................................

Research Objectives .............................................................. 1

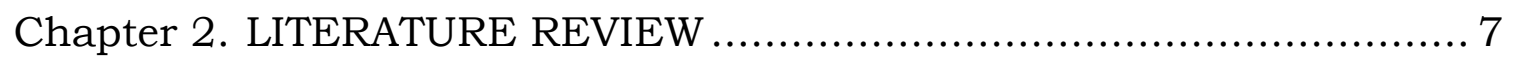

CWD Pacific Northwest Ecology................................................ 7

CWD Dynamics in PNW Westside Forests................................... 9

Structural Legacies of Wind Disturbance .................................... 10

CWD Regeneration Dynamics and Micro-succession .................... 19

Chapter 3. STUDY SITE …...................................................

Sitka Spruce-Western Hemlock Forest Type................................ 25

Cummins Creek Vegetation ................................................... 27

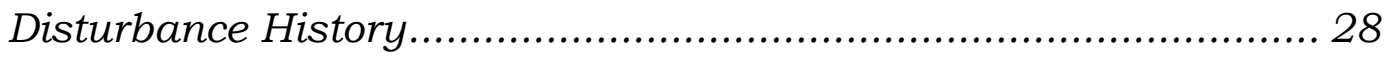

Chapter 4. METHODS ......................................................... 30

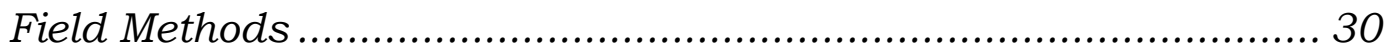

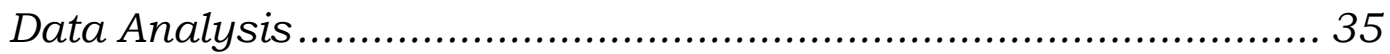

Chapter 5. RESULTS ...................................................... 44

Community Composition between Substrates ............................. 44

Community Composition Patterns on CWD ............................... 57

Non-Decay Class Factors Affecting Understory Composition on Logs

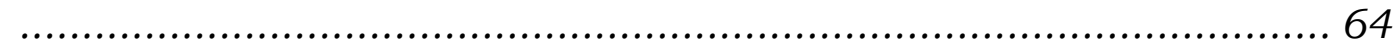

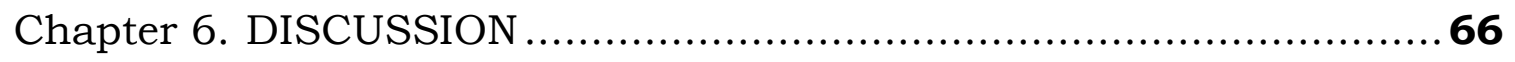

Substrate Community Composition .......................................... 66

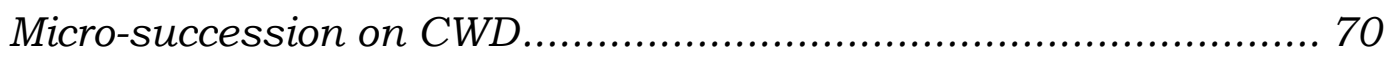

Chapter 7. CONCLUSIONS.......................................................... 75

Chapter 8. REFERENCES .........................................................

Chapter 9. APPENDIX A: NMDS BUBBLE PLOTS OF SPECIES ........... 89 


\section{LIST OF TABLES}

Table 1. Review of literature on seedling, bryophyte, and understory regeneration on CWD............................................. 14

Table 2. Characterization of decay class of fallen trees ...................... 31

Table 3. Daubenmire (1959) Cover Classifications.............................. 34

Table 4. Individual species and plant group averages by substrate ...... 45

Table 5. Diversity measures by substrate ...................................... 56

Table 6. Pair-wise Analysis of Similarities (ANOSIM) by substrate. ....... 64

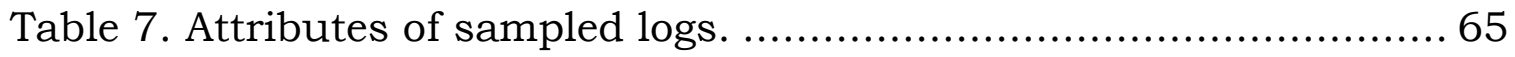




\section{LIST OF FIGURES}

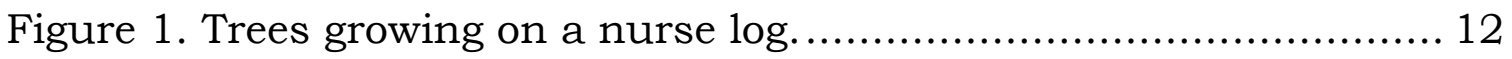

Figure 2. Micro-succession sere on CWD. ................................... 22

Figure 3. Map of Cummins Creek Wilderness, Oregon........................ 24

Figure 4. Sitka spruce-western hemlock distribution. ...................... 26

Figure 5. Quadrat sampling on $\log$ surface.................................... 33

Figure 6. Methods and research objectives.................................... 36

Figure 7. Frequency charts showing paired differences ..................... 47

Figure 8. Percent cover charts showing paired differences .................. 48

Figure 9. NMDS ordination of study sites ..................................... 50

Figure 10. Notched boxplots of ANOSIM values of sites ..................... 51

Figure 11. Dendrogram of sites labeled by substrate type.................. 53

Figure 12. NMDS of sites, species scores, and cluster hulls................ 54

Figure 13. Dendrogram of sites by decay class ............................... 57

Figure 14. NMDS bubble plots of the shrub and seedling group. ......... 59

Figure 15. NMDS bubble plots of the fern group............................... 60

Figure 16. NMDS bubble plots of the forb group............................... 61

Figure 17. Notched boxplots of ANOSIM values for sample plots.......... 63

Figure 18. Summary of hypotheses and research outcomes. ............... 76 


\section{INTRODUCTION}

\section{Research Objectives}

This study investigates the effects of the structural legacies created by fine-scale wind disturbance on understory diversity and succession of old-growth Pacific Northwest (PNW) forests in western Oregon. Specifically, I examine how coarse woody debris (CWD), i.e., logs exceeding $10 \mathrm{~cm}$ in diameter, derived from uprooted trees and windsnapped boles influence patterns of understory composition and microsuccession in an old-growth, Sitka spruce (Picea sitchensis)-western hemlock (Tsuga heterophylla) forest near the Oregon coast. Using understory census data for seedlings, saplings, shrubs, and herbs, I compare the community composition between fallen logs and the forest floor and examine how these patterns shift over time. Succession and colonization patterns on these substrates are analyzed using a space-fortime substitution that compares logs of differing stages of decomposition (i.e., time since uprooting or windsnap). I explore understory data with ordination and cluster analyses to reveal how composition relates to substrate type and decay class.

My research demonstrates how fine-scale wind disturbance fosters biodiversity in a coastal Oregon, old-growth forest through the creation of 
CWD substrate. Similar to studies in other westside forests (e.g., Pabst and Spies 1998; Kennedy and Quinn 2001; Six and Halpern 2008), I hypothesize that CWD supports distinct assemblages of plant communities, with similar levels of diversity, from the forest floor. I also hypothesize that CWD assemblages will reflect decay class of log and show an eventual convergence with forest floor communities as logs decay and are colonized by forest floor species. Results of this study may differ from previous research consistent with autecological (life-history) attributes and a complex disturbance history characterized by frequent and severe windstorms. This research will contribute toward a broader comparison of the role of CWD across forest types and clarify how oldgrowth forests differ from their human-modified counterparts with respect to the succession and spatial patterns of understory communities.

\section{Micro-Succession}

Vegetation dynamics is the study of short- and long-term temporal and spatial changes within and among plant communities (Miles 1978). These changes include seasonal responses to changing environmental conditions (e.g., growth and dormancy) and post-disturbance directional changes in species composition and community structure inherent to 
ecological succession (Clements 1916; White 1979; Sousa 1984; Huston and Smith 1987; Pickett et al. 1987). Although succession research is not limited to a specific spatial and temporal scale, contributions to succession theory are typically garnered through scale-dependent case studies that act as tests of the theory's overall efficacy (e.g., Houssard et al. 1980; Fonda 1974; Halpern 1988; Weber et al. 2006). As a result, succession-related research commonly occurs at the micro- to regional scale and across a suite of environmental conditions.

One example of micro-succession is the examination of understory colonization, composition, and diversity patterns on fallen logs. This area of research has revealed clear substrate affinities of understory species and has described community assemblage on decomposing logs for several forest types including eastern deciduous (Thompson 1980; Pyle and Brown 2002), northern hardwood (McGee 2001), subalpine spruce-fir (McCullough 1948), boreal spruce forests (Kushnevskaya et al. 2007), and aspen-dominated boreal forests (Lee and Sturgess 2001). Limited research has been conducted in PNW forests (but see: Six and Halpern 2008; Kennedy and Quinn 2001) where fallen logs are a common structural legacy of the local natural disturbance regimes (Harmon et al. 1986). 


\section{Structural and Biological Legacies}

Structural and biological legacies are pre-disturbance, residual organic matter that include organisms, abiotic structures, or enduring biologically created patterns (Franklin et al. 2007). CWD in varying stages of decomposition are structural legacies that "lifeboat," or maintain species in situ (Franklin et al. 2007). These legacies foster biological diversity by providing energy, nutrients, and new habitat for colonization while increasing the diversity of physical and microclimatic conditions of a forest.

Wind disturbance is a key exogenous (external) factor contributing to structural heterogeneity and substrate-related differences in microsuccession. Wind is a globally important disturbance agent influencing forest composition, structure, and succession in tropical and northern boreal forests (Falinski 1978; Boose et al. 1994; Bormann et al. 1995; Ullanova 2000). In mid-latitude regions, such as Western Europe, South America and North America, windstorms can result in vast areas of forest blowdown (Ruth and Yoder 1953; Peterson et al. 1990; Veblen et al. 1996) causing high stem mortality (e.g., Harmon et al. 1986) and structural legacies in the form of canopy gaps (Everham and Brokaw 1996; Lertzman et al. 1996;), CWD (Harmon et al. 1986), and pit-andmound microtopography (Beatty and Stone 1985; Maser et al. 1988; 
Schaetzl et al. 1990). This structural heterogeneity influences community vegetation dynamics, soil development, nutrient cycling, forest productivity, and biodiversity (Lutz 1940; Schaetzl et al. 1989; Rambo 2001).

Structural legacies and dead wood are an essential component of silvicultural models or "ecological forestry" that promote biodiversity (Lindenmayer et al. 2006; Franklin et al. 2002; Franklin et al. 2007) yet little is known about the relationship between CWD and understory diversity and successional pathways in PNW old-growth forests. Historical trends in management practices focused on commercial wood production and the prevention of forest fires through the removal of all dead wood from a stand. Contemporary landscape-scale management goals seek to integrate biological diversity and ecological integrity with traditional economic objectives by replicating natural disturbance regimes and cultivating the structural heterogeneity typical of latesuccessional forests (Hansen et al. 1991; Swanson and Franklin 1992; Beese et al. 2003).

Studies examining the relationship between the structural legacies of CWD substrates and understory composition and diversity in the Pacific Northwest exist for second-growth stands in the western Cascades (Kennedy and Quinn 2001; Six and Halpern 2008) but are absent for oldgrowth forests characterized by high levels of CWD resulting from high 
forest productivity, frequent wind storms, and slow decomposition rates (Maser and Trappe 1984). In these forests, fallen trees persist in various states of decay, further increasing structural heterogeneity as the ecological functions of CWD shift throughout the decomposition process (Maser et al. 1988).

\section{Thesis Outline}

This thesis details the completion of my research objectives. Chapter 2, the Literature Review, discusses the broad ecological role of CWD in Pacific Northwest forests and outlines previous studies regarding CWD as regeneration sites for trees, bryophytes, and vascular plants. My study site and methods are described in Chapters 3 and 4, respectively. I present my results in Chapter 5, followed by my discussion of the data in Chapter 6. Chapter 7 presents the conclusion to this research. 
LITERATURE REVIEW

CWD Pacific Northwest Ecology

Nutrient Dynamics

Nutrient input and storage dynamics of CWD vary among forest types and throughout the decomposition process. In the PNW, CWD comprises the majority of accumulated organic matter (Harmon et al. 1986) but is initially a minor source of nutrient input relative to needle and leaf litter (Grier 1978; Harmon and Hua 1991). Nutrient cycling of fine litter in PNW forests typically occurs within 10-50 years versus 400 years for large logs (Maser et al. 1988). The nutrient concentrations of CWD are relatively low in recently fallen logs and increase as logs reach advanced stages of decay (Harmon et al. 1986).

Notwithstanding its low nutrient concentrations, the high abundance of CWD makes it an important nutrient source. In oldgrowth Douglas-fir forests, $>30 \%$ of soil organic matter content is derived from large, fallen trees contributing more than four times the organic content of other sources (Maser et al. 1988). CWD also acts as a large terrestrial carbon sink (Harmon and Hua 1991). 
Forest productivity in PNW westside forests-forests located west of the Cascade crest—is considered nitrogen limited (Maser et al. 1988). Symbiotic nitrogen fixation and rainfall contribute half of the annual volume of nitrogen in these forests (Maser et al. 1988). CWD plays an important supplemental role by supporting nitrogen fixing bacteria that provide an estimated one-eighth of the total annual $\mathrm{N}$ input (Harmon et al. 1986; Spears et al. 2003). CWD also supports higher rates of $\mathrm{N}$ fixation and populations of $\mathrm{N}$-fixating organisms than adjacent soils in both old-growth and logged coastal forests (Crawford et al. 1997).

CWD Habitat

Decaying snags and logs in PNW forests increase faunal biodiversity by providing cavity sites, shelter, foraging sites, and food and energy for vertebrates, invertebrates, fungi, and microbes (Maser and Trappe 1984; Harmon et al. 1986; Bunnell et al. 2002). Bunnell et al. (2002) found 69 vertebrate species commonly used cavities in decaying wood and an additional 47 species preferred sites with higher levels of downed wood. Over one-half of the Pacific Northwest vertebrates listed as "at risk" or "sensitive" are strongly associated with snags or fallen logs (Bunnell et al. 2002). Habitat functions of CWD change throughout the decomposition process. For example, logs initially provide elevated 
runways and concealed spaces for vertebrates while gradually increasing in importance for invertebrate and insectivore habitat as the wood softens and collapses (DeLong et al. 2005).

\section{CWD Dynamics in PNW Westside Forests}

Wind disturbance is a major cause of large tree mortality resulting in both isolated tree falls and catastrophic blowdown (e.g., Schaetzl et al. 1990; Everham and Brokaw 1996). Uprooting and windsnap may be one of the most influential disturbance agents in westside forests (e.g., Hadley and Knapp 2011) causing high stem mortality (Harmon et al. 1986) and large (Maser and Trappe 1984) but variable accumulations of CWD (Edman et al. 2007). CWD concentrations correspond to the successional stage of a stand (Ohmann and Waddell 2002) with accumulation in the form of decaying snags, logs, and stumps.

Oregon's old-growth forests have high levels of CWD compared to other forest types, resulting from high forest productivity, frequent highspeed winds, and slow decomposition rates (Maser and Trappe 1984). CWD biomass accumulations of 175 (Harmon et al. 1986) to 220 tons per acre (Agee and Huff 1987) reported for PNW westside forests exceed the total live and dead wood found in eastern deciduous forests. Other PNW studies found decaying wood covering 5 to $70 \%$ of the forest floor 
(Harmon and Sexton 1995) and contributing ca. 50\% of forest litter on a long-term basis (Sollins 1982). By comparison, CWD covers between $1.6-4 \%$ of the forest floor in other regions (Christy and Mack 1984).

The distribution of CWD in PNW forests is generally patchy, where more than half of the total volume of CWD may be contained in $<20 \%$ of a stand's total area (Harmon et al. 1986). This pattern follows the patchy nature of mortality-inducing disturbance and the distribution of the large, old trees that increase the CWD supply.

Structural Legacies of Wind Disturbance

Low-severity wind disturbance results in the episodic uprooting or windsnap of individual trees thereby increasing microsite variability and creating new habitat for colonization (McCullough 1948; Beatty 1984; Everham and Brokaw 1996; Rambo 2001). The resulting fine-grain structural heterogeneity promotes plant diversity and is a key feature of old-growth forests (Franklin and Van Pelt 2004). Uprooting creates microsites in the form of canopy gaps, pit and mound microtopography, and nurse logs (Schaetzl et al. 1989).

Pit and mound soils differ from undisturbed forest soils as a result of the redistribution of surface organic matter and subsoil, mixing and burying of horizons (floralturbation), bare mineral soil exposure, and 
microtopographic variation (Stephens 1956; Schaetzl et al. 1989a;

Bormann et al. 1995; Beatty and Stone 1985.) Mounds are characterized by increased porosity and aeration, higher summertime temperatures, greater temperature variability, low bulk density, and thin litter cover (Lutz 1940; Schaetzl et al. 1990). Conversely, pits commonly have saturated conditions, lower rates of permeability, and accumulations of organic matter (Bormann et al. 1995).

Nurse logs—logs supporting live seedlings, trees, shrubs, and herbaceous plants-are common to many forest types but occur in the highest concentration in Sitka-spruce zone of the PNW (Harmon and Franklin 1989). These logs increase substrate heterogeneity and lead to linear patterns of tree growth and stilt-rooted trees (Franklin and Dyrness 1973) (Figure 1). 


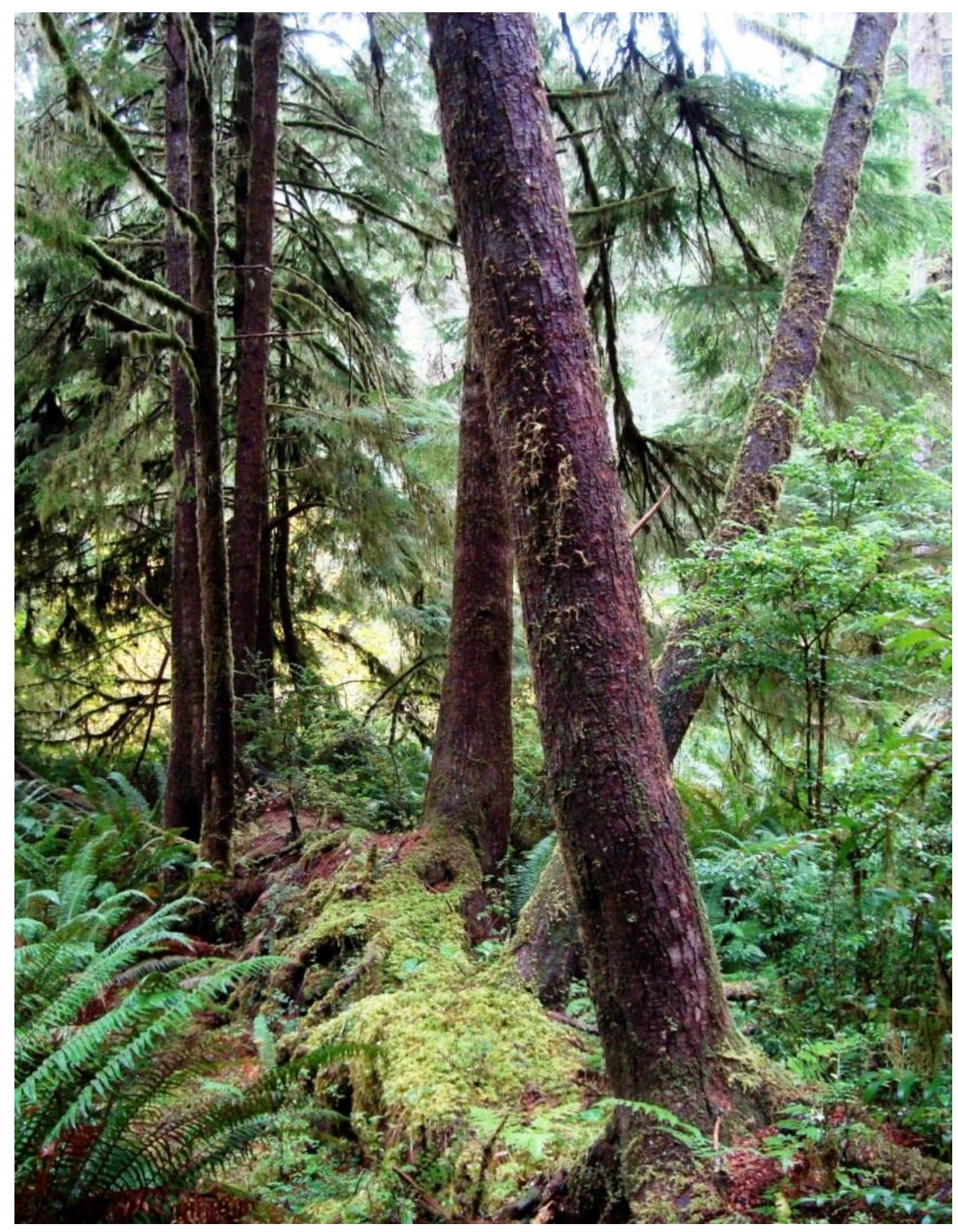

Figure 1. Trees growing on a nurse log in the Cummins Creek study site. Shannon McDonald, photo 2009. 
Seedling Regeneration on Nurse logs

The role of logs as a regeneration substrate for late-seral tree species is well-documented for westside forests (Minore 1979; Harmon et al. 1986; Spies et al. 1988) (Table 1). In the Sitka spruce-western hemlock forests of the Olympic Peninsula, Harmon and Franklin (1989) found nurse logs covering $6-11 \%$ of the forest floor but acting as substrate for $88-97 \%$ of tree seedlings. Christy and Mack (1984) observed $98 \%$ of western hemlock seedlings in the western Cascades occurring on the $6 \%$ of the forest floor by CWD.

Harmon (1986) determined that competition with mosses and herbs resulted in low seedling survival rates on the forest floor. Increased light levels explained the higher regeneration rates on logs among possible factors of predation, pathogens, competition, standing water, seed penetration, and allelochemical reactions (Harmon and Franklin 1989). 
Table 1. Review of literature on seedling, bryophyte, and understory regeneration on CWD. Shaded cells indicate micro-successional patterns.

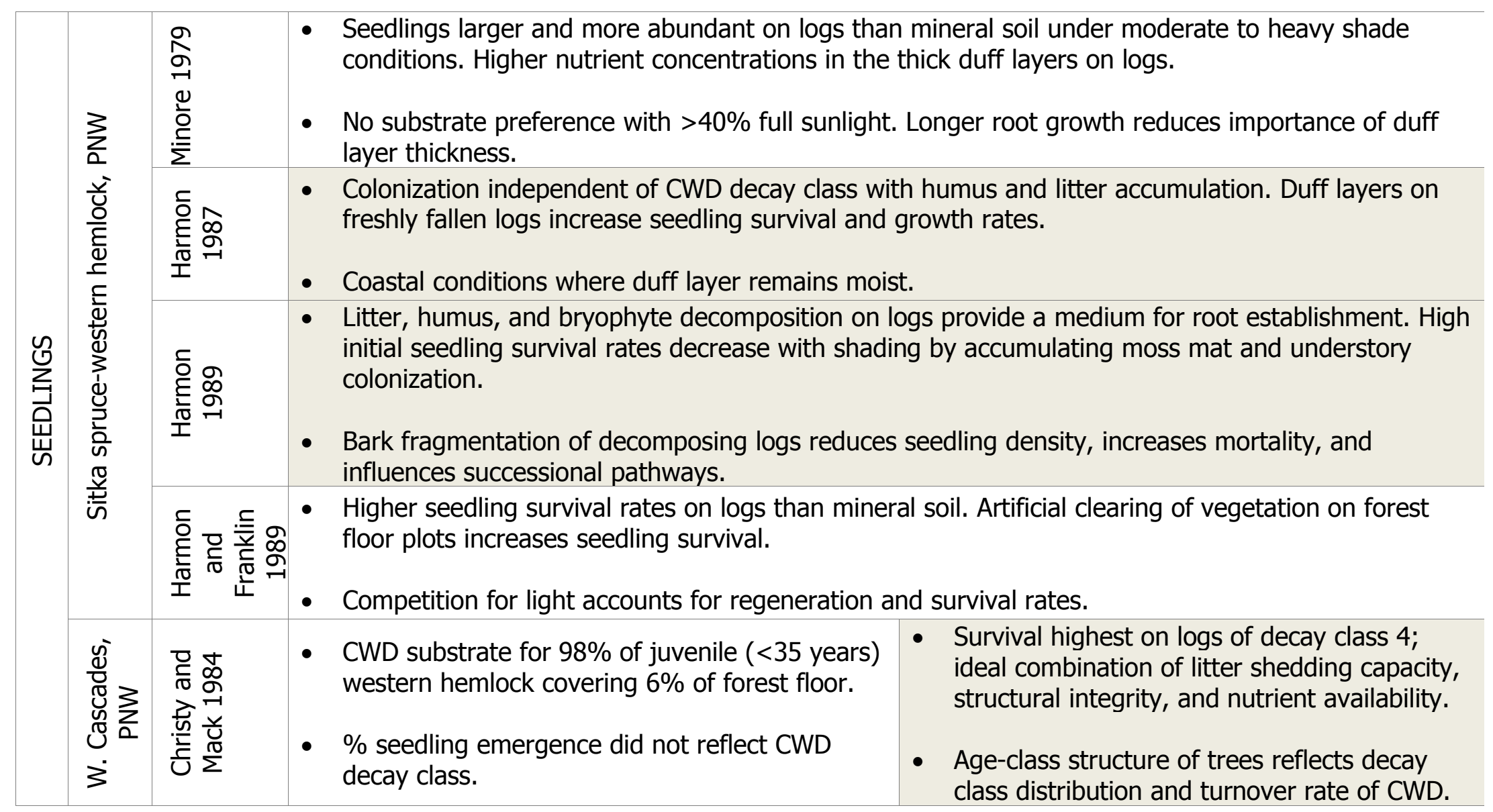




\begin{tabular}{|c|c|c|c|c|}
\hline \multirow{2}{*}{ 嵌 } & \multirow{2}{*}{ 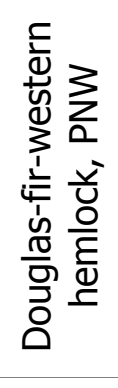 } & 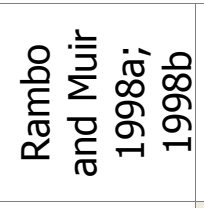 & $\begin{array}{l}\text { Distribution of CWD may explain local-scale } \\
\text { patterns of bryophyte diversity. } \\
\text { - Bryophyte richness maximized in presence of } \\
\text { CWD in varying states of decay. }\end{array}$ & $\begin{array}{l}\text { - Community composition reflected CWD decay } \\
\text { class. }\end{array}$ \\
\hline & & 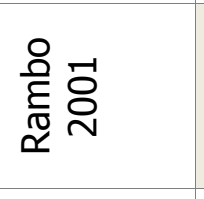 & $\begin{array}{l}\text { - Highly decayed logs had greatest richness an } \\
\text { - Logs in advanced decay are closer to the grol } \\
\text { microclimate than less decayed CWD. }\end{array}$ & $\begin{array}{l}\text { umber of unique species. } \\
\text { and provide a more stable and humid }\end{array}$ \\
\hline \multirow{5}{*}{ 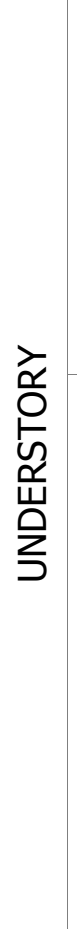 } & \multirow{2}{*}{$\sum_{a}^{3}$} & 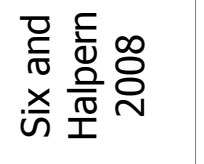 & $\begin{array}{l}\text { - } 62 \% \text { of species exhibited a preference for the } \\
\text { species occurred on both substrates }(n=29) \text {. }\end{array}$ & st floor and $21 \%$ associated with CWD. Most \\
\hline & & 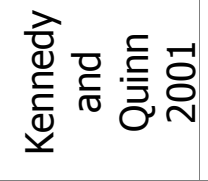 & $\begin{array}{l}\text { - Substrates support distinct plant communities } \\
\text { - Compositional differences between substrates } \\
\text { - Reduced competition for light on stumps. }\end{array}$ & $\begin{array}{l}\text { h similar diversity levels. } \\
\text { eater in deciduous than coniferous sites. }\end{array}$ \\
\hline & \multirow{3}{*}{ 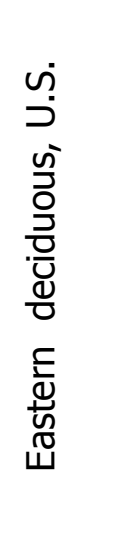 } & 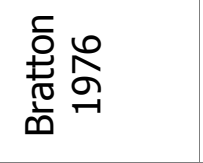 & $\begin{array}{l}\text { - Several herb species exhibited preference for } \\
\text { - Patterns of species composition on microsites } \\
\text { morphology. }\end{array}$ & ult from resource partitioning and plant \\
\hline & & 过 & $\begin{array}{l}\text { - One species (wood fern) exhibited a CWD sub } \\
\text { - Thin glacial till soils may provide comparable } \\
\text { - Some deep-rooted herb species were negativ }\end{array}$ & $\begin{array}{l}\text { ate affinity. } \\
\text { ving conditions to CWD. } \\
\text { associated with CWD. }\end{array}$ \\
\hline & & 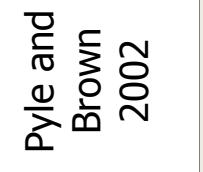 & $\begin{array}{l}\text { - Vascular plants and seedlings more frequent } \\
\text { increased with decay class. }\end{array}$ & est floor sites than CWD. Frequency on logs \\
\hline
\end{tabular}




\begin{tabular}{|c|c|c|c|c|}
\hline \multirow{3}{*}{ 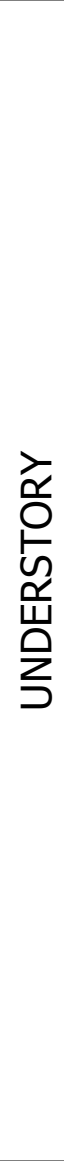 } & & & \multicolumn{2}{|c|}{$\begin{array}{l}\text { - Successional patterns on logs vary with environmental conditions (mesic, bog, or xeric). General } \\
\text { trend of bryophytes then herbaceous plants followed by shrubs, if present. } \\
\text { - Assemblages correspond to decay class. } \\
\text { - Seedling establishment may occur at any stage. }\end{array}$} \\
\hline & & 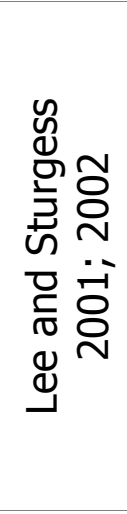 & $\begin{array}{l}\text { - Affinity for CWD shown by shade-tolerant forbs } \\
\text { and tree seedlings. Grasses, shrubs, and shade- } \\
\text { intolerant forbs associated with the forest floor. } \\
\text { - Compositional differences of microsites may be } \\
\text { a function of competitive release. } \\
\text { - Forest floor had highest richness. CWD richness } \\
\text { increased with decay class and DBH. }\end{array}$ & $\begin{array}{l}\text { - Species assemblages reflect decay class. } \\
\text { Patterns influenced by physical properties of } \\
\text { CWD. } \\
\text { - Composition between log and ground } \\
\text { substrates converged with increasing CWD } \\
\text { decay class. } \\
\text { - Physical lowering of CWD with } \\
\text { decomposition facilitates invasion by forest } \\
\text { floor plants. }\end{array}$ \\
\hline & 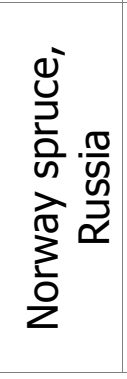 & 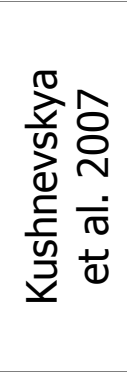 & \multicolumn{2}{|c|}{$\begin{array}{l}\text { - CWD bryophyte and vascular species composition related to decay class and forest type. } \\
\text { Vegetation patterns and decay class linked but suggest micro-succession and decomposition are } \\
\text { discrete processes. } \\
\text { - Successional pathways vary with dominant ground vegetation. Characterized by early dominance o } \\
\text { bryophytes, a late-stage increase in vascular plants, and a steady decrease in diversity and } \\
\text { evenness. }\end{array}$} \\
\hline
\end{tabular}


Bryophytes

Bryophytes are important indicators of biodiversity because of their relative numerical and spatial dominance, and sensitivity to anthropogenic disturbance (Frego 2007). Logs in advanced stages of decay in Oregon's Coast and Cascade ranges typically exhibit high bryophyte diversity (Rambo and Muir 1998a; Rambo 2001) (Table 1). Rambo (2001) found logs in advanced stages of decay supported the greatest percentage of local-scale bryophyte diversity, the greatest number of bryophyte species unique to a substrate type, and the highest levels of species richness among seven other sampled substrates. Highly decayed logs provided habitat for $83 \%$ of all liverwort and $55 \%$ of all moss species (Rambo 2001).

\section{Understory Species}

Earlier research on the understory composition, distribution, and diversity of PNW forests identified several factors contributing to understory community development. Foremost among these factors are environmental gradients resulting from disturbance history (Alaback 1982; Stewart 1988; Suchar and Crookston 2010), canopy structure, 
(Alaback and Herman 1988; Bailey et al. 1998; Van Pelt and Franklin 2000), landforms, and geomorphic influences (Fonda 1974; Hanley and Brady 1997; Pabst and Spies 1998). Few studies, however, have investigated the role of CWD in understory plant distributions and diversity in PNW forests.

PNW studies that examined the relationship between CWD and understory vegetation include Pabst and Spies' (1998) research along the central Oregon coast, Kennedy and Quinn's (2001) work on the Olympic Peninsula, and Six and Halpern's (2008) study in the western Cascades of central Washington. Pabst and Spies' (1998) research revealed that moisture gradients associated with hillslope processes, in addition to microsite conditions on logs explained vegetation patterns in riparian forests. These results are similar to those presented by Nakashizuka (1989) who demonstrated enhanced understory diversity in areas experiencing uprooting and canopy gap formation.

Structural legacies and CWD are important factors contributing to understory richness in deciduous and coniferous forests (Kennedy and Quinn 2001; Six and Halpern 2008) (Table 1). Kennedy and Quinn's (2001) research of understory species growing on old-growth conifer stumps showed similar levels of species richness, evenness, and diversity on stump and forest floor substrates with distinct understory communities. Salal (Gaultheria shallon) and red huckleberry (Vaccinium 
parvifolium) were the dominant species on CWD while Pacific blackberry (Rubus ursinus) and sword fern (Polystichum munitum) dominated the forest floor.

Similar to Harmon and Franklin's (1989) research on seedlings, Kennedy and Quinn (2001) attributed dissimilarities in composition between the forest floor and the elevated stumps to differences in light levels. These studies differ from Kennedy and Quinn's (2001) results that showed primary light competitors were woody shrubs rather than nonvascular plants. They also found the most pronounced difference in composition occurred under deciduous trees where higher subcanopy light levels favor a dense salmonberry (Rubus spectabilis) understory. Within the deciduous forest sites, stumps provided refugia for species typically outcompeted by salmonberry on the forest floor. Microsite variation associated with stumps increased community richness and explained spatial patterns of species composition (Kennedy and Quinn 2001).

CWD Regeneration Dynamics and Micro-Succession

Harmon (1989) documented changes in seedling composition on conifer logs in the Sitka spruce-western hemlock forests of the Olympic Peninsula as a function of time on the forest floor and bark 
fragmentation. Litter accumulation on logs permits seedling establishment on non-decayed CWD although the intact bark of freshly fallen trees resists root establishment (Harmon 1987) (Figure 2). Decayed CWD initially facilitates a high seedling survival rate. Longterm survival rates decrease with bark fragmentation and seedling competition or self-thinning (Sharpe 1956; Harmon 1989). Subsequent bark sloughing removes established plants, "reinitiating the sere" (Harmon 1989). Competitive interactions between species also influenced successional pathways. For example, bryophyte colonization on logs initially increases tree-seed retention but eventually hinders seedling establishment by shading from well-developed moss layers (Harmon 1989). Studies with an explicit focus on micro-succession patterns of understory species regeneration on CWD are lacking in PNW coastal forests.

Succession on CWD is influenced by species interactions and the physical decomposition of the substrate. Studies describing the temporal pattern of understory colonization are limited. Generally, bryophyte colonization precedes low-growing herb colonization on logs followed by woody shrubs and trees (McCullough 1948; Lee and Sturgess 2001). Kushnevskaya et al. (2007) characterized four stages of micro-succession on decaying spruce logs in late succession forests in northwest Russia. The first stage has the fewest species but highest diversity and evenness 
as most species have single occurrences. The second stage, with both initial colonizers and active colonization of new species, has the highest bryophyte richness. Bryophyte richness progressively lowers throughout the third and fourth stage as a result of competitive exclusion. Vascular plant richness peaks in the final stage while diversity indices decrease, suggesting a stable community. 


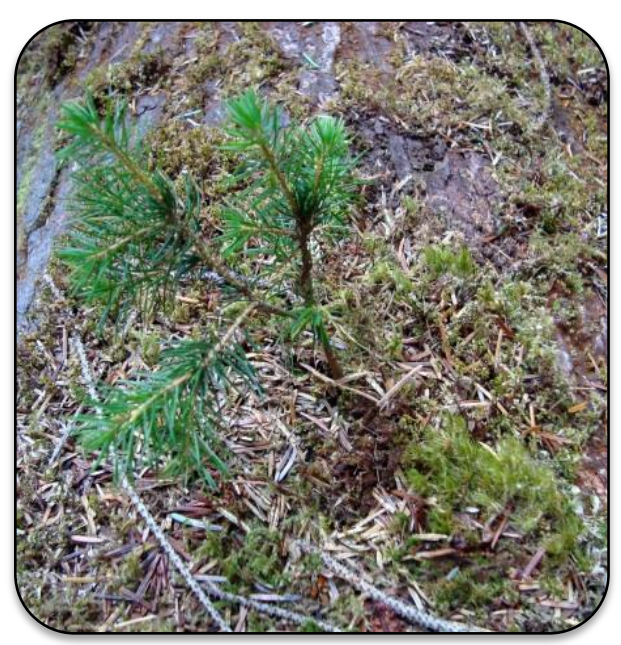

Initial

- Floristic relay

- Small bryophtye and lichen species increase establishment by retaining moisture and airborne seeds

- Litter layer development

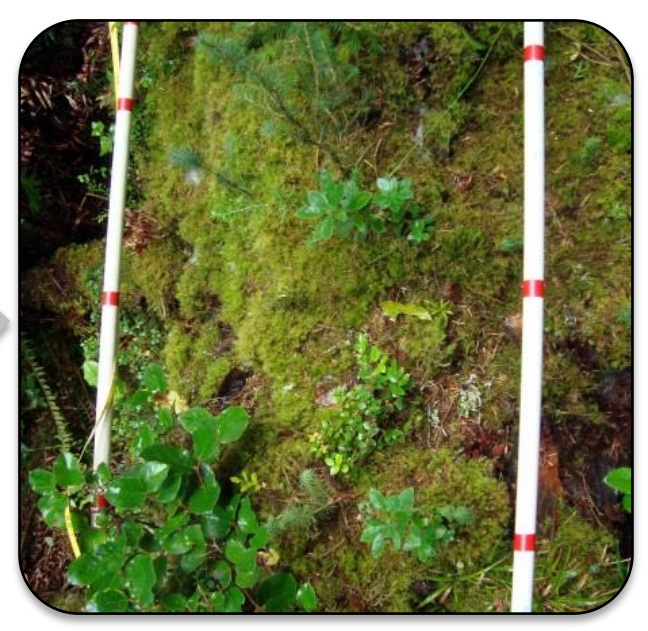

\section{Intermediate}

- Physical properties of substrate (light levels)

- Bryophyte colonization and decomposition, accumulation of humus layer

- Herbs and shrubs unable to compete on forest floor

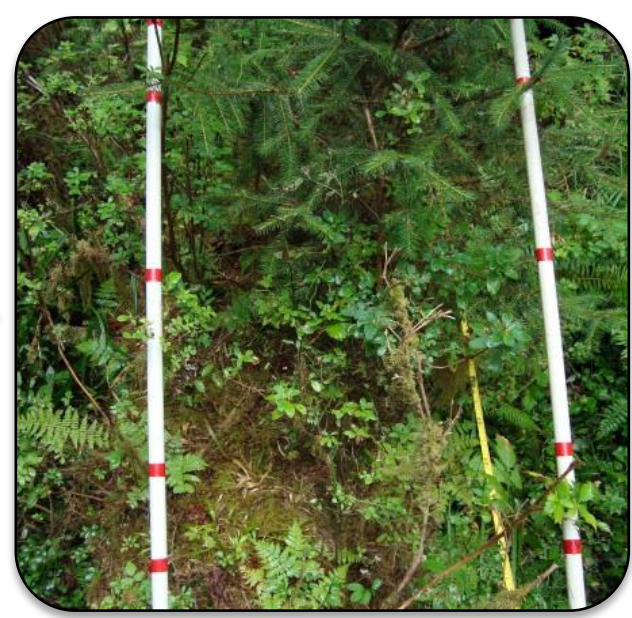

\section{Advanced}

- Competitive interaction

- Further seedling establishment prevented by shading from thick moss layer and understory colonization

- Self-thinning

- Bark sloughing, sere reinitiation

Figure 2. Micro-succession sere on CWD. Source: Harmon 1989; Rambo 2001; Kushnevskaya et al. 2007. Photos: Shannon McDonald. 


\section{STUDY SITE}

My study site is located in the Cummins Creek Wilderness along the central Oregon Coast $\left(44^{\circ} 15^{\prime} \mathrm{N} 124^{\circ} 05^{\prime} \mathrm{W}\right)$ (Figure 3). Designated in 1984, this wilderness area occupies 3,900 ha within the Siuslaw National Forest and contains three drainages between the western slopes of the Oregon Coast Range and the Pacific Ocean. The site includes the only old-growth Sitka spruce forest in an Oregon wilderness area and represents one of the few remaining coastal old-growth stands in Oregon (USFS 2013). This unique status provides a rare opportunity to examine the baseline conditions of riparian old-growth forests needed to develop informed management practices and standards for riparian ecosystems in the Oregon Coast Range (Nierenberg and Hibbs 2000).

Climate conditions at Cummins Creek are typical of Oregon's temperate rainforests, with mild winters and growing season temperatures ranging from $10^{\circ}$ to $20^{\circ} \mathrm{C}$ (Wimberly and Spies 2001). Most precipitation $(180 \mathrm{~cm} /$ year) falls between November-March (Wimberly and Spies 2001) yet cool summer temperatures and coastal fog prevent moisture stress during the growing season. Cummins Creek soils include Andisols and Inceptisols underlain by Yachats basalt (Wimberly and Spies 2001). These soils consist of silty loams developed from igneous rock-derived colluvium with a surface layer of decaying 
needles, leaves, and twigs $1-8 \mathrm{~cm}$ thick (Patching 1981). Local terrain consists of stream terraces adjacent to steep dissected slopes. Elevations within the wilderness area range from near sea level to $>800 \mathrm{~m}$ along its eastern edge (Wimberly and Spies 2001).

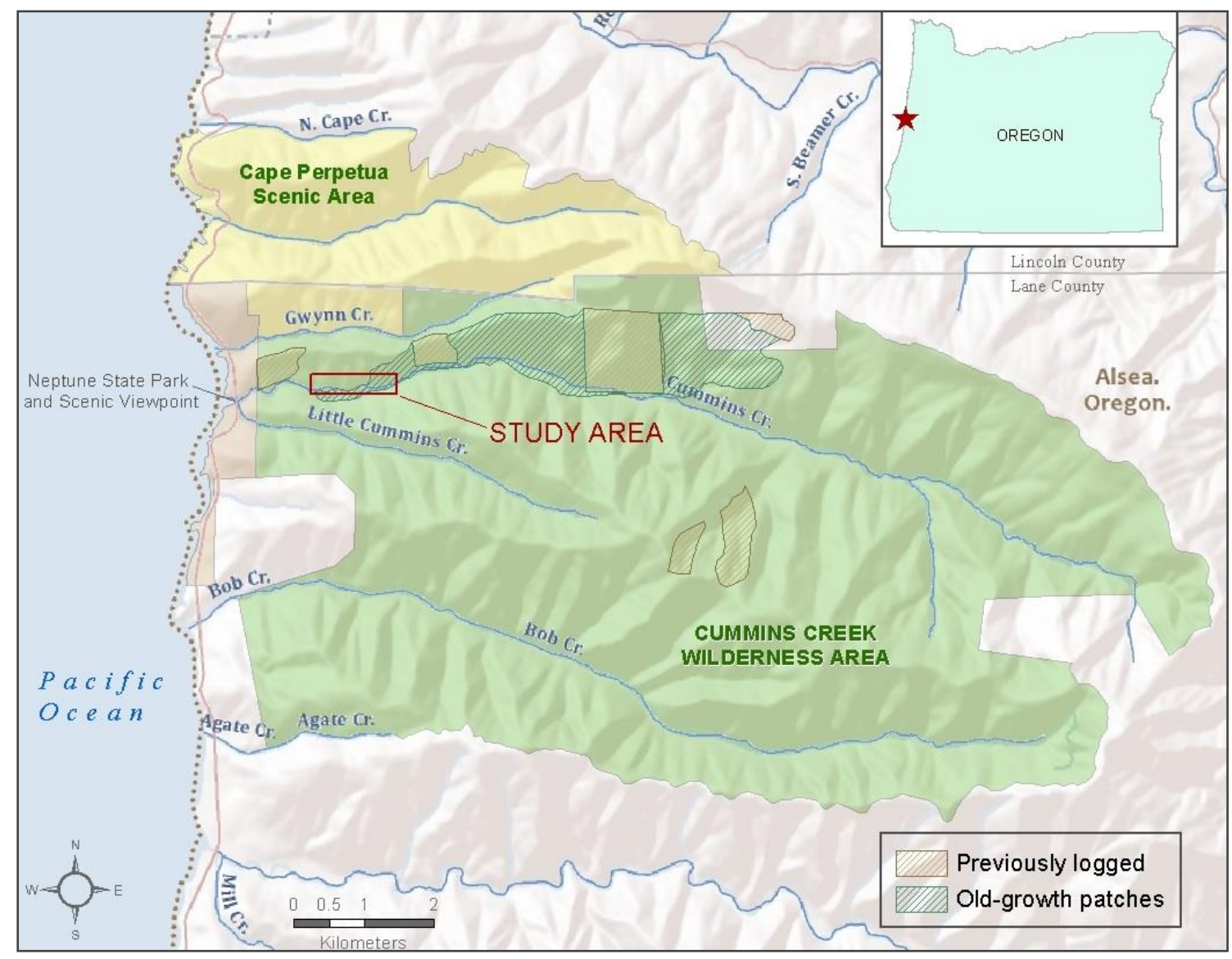

Figure 3. Map of Cummins Creek Wilderness, Oregon. Demarcation of patches from Wimberly and Spies (2001). Map adapted from Bambrick (2013). 
Sitka Spruce-Western Hemlock Forest Type

Cummins Creek is situated within the Sitka spruce-western hemlock zone that encompasses over $20^{\circ}$ latitude and 3,000 km of coastline from southern Alaska to northern California (Franklin and Dyrness 1988) (Figure 4). Sitka spruce is a drought-intolerant species closely associated with the coastal fog belt (Franklin and Dyrness 1988). In Oregon, its range is a few kilometers in width, extending further inland along low-elevation river valleys up to $30 \mathrm{~km}$ (Ruth and Harris 1979).

Old-growth hemlock-spruce forests of the Pacific Northwest are among the most productive forests in the world (Ruth and Harris 1979). Exceptional above-ground biomass levels result from the longevity of large-statured dominant trees with high leaf area indices. On select sites, typical Sitka spruce trees may live for over 500 years and reach heights of $75 \mathrm{~m}$ with diameters of $180-230 \mathrm{~cm}$ (Waring and Franklin 1979). Western hemlocks often exceed 400 years with heights of 50-65m and diameters of 90-120 cm (Waring and Franklin 1979). Biomass accumulation is further facilitated by the mild maritime climate, allowing for year-round photosynthesis. 


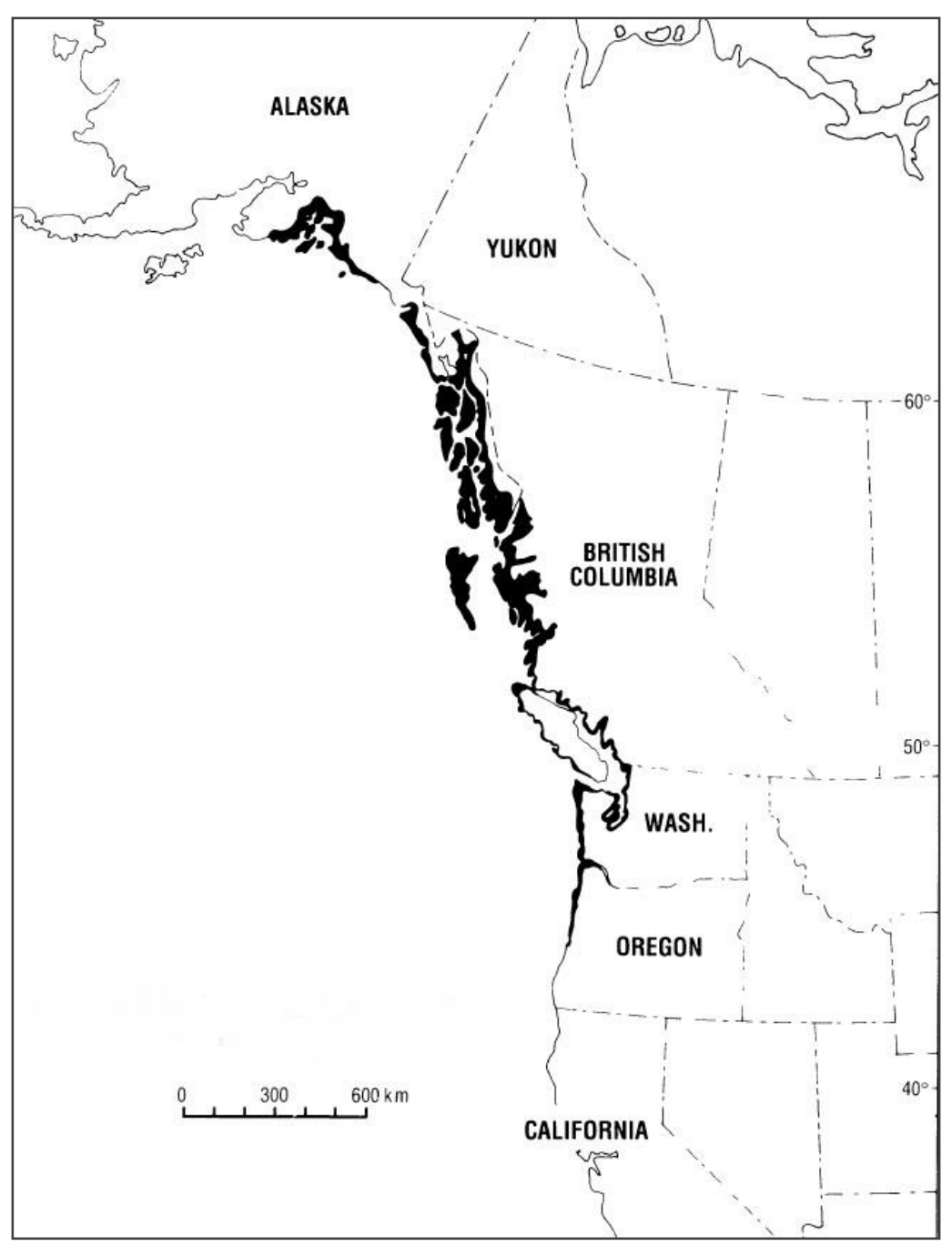

Figure 4. Sitka spruce-western hemlock distribution. Adapted from Ruth and Harris (1979).

Western hemlock, the most shade tolerant of western conifers (Minore 1979), is the dominant steady state species in the Sitka sprucewestern hemlock forest zone. Western hemlock may outnumber Sitka spruce by a factor of two except in the coastal spray zone where Sitka spruce may form pure stands or co-dominate with shore pine (Pinus contorta var. latifolia) (Franklin and Halpern 1999). Although western 
hemlock's density, shade tolerance, and recruitment rates exceed those of Sitka spruce, the latter is a stable constituent of this forest zone (Greene et al. 1992; Taylor 1990). Sitka spruce seedlings have higher survival and higher growth rates under the large canopy gaps typical among wind-disturbed, old-growth stands along the Oregon coast (Taylor 1990). Spruce also have lower mortality and greater longevity than hemlock (Greene et al. 1992) and only require large canopy gaps every several decades for coexistence (Taylor 1990).

\section{Cummins Creek Vegetation}

Forest associates of the Cummins Creek Wilderness include Douglas-fir (Pseudotsuga menziesii), western red cedar (Thuja plicata), grand fir (Abies grandis), and bigleaf maple (Acer macrophyllum). Hardwoods such as red alder (Alnus rubra) and vine maple (Acer circinatum) are co-dominant along streams or recently disturbed sites (Franklin and Halpern 1999).

Understory vegetation at Cummins Creek is characterized by a dense cover of tall plants with high species diversity, similar to that of other westside old-growth forests in western Oregon and Washington (Ruth and Harris 1979). Under modal environmental conditions, western sword fern (Polystichum munitum), redwood sorrel (Oxalis oregano), false 
lily of the valley (Maianthemum dilatatum), three leaf foam flower (Tiarella trifoliate), evergreen violet (Viola sempervirens), yellow mountain violet ( $V$. glabella), Smith's fairybells (Disporum smithii), red huckleberry (Vaccinium parvifolium), and false azalea (Menziesia ferruginea) are typical herbs and shrub species (Franklin and Dyrness 1988). Hydric sites include devil's club (Oplopanax horridum), lady fern (Athyrium filixfemina), deer fern (Blechnum spicant), shield fern (Dryopteris austriaca), red elderberry (Sambucus racemosa) and coast red elderberry (Sambucus callicarpa). Salal (Gaultheria shallon), Pacific rhododendron (Rhododendron macrophyllum), and evergreen huckleberry (Vaccinium ovatum) are common on old sand dunes, steep slopes, and less favorable sites.

\section{Disturbance History}

The Oregon Coast Range experienced multiple large fires between the mid-19th and early $20^{\text {th }}$ centuries (Impara 1997; Nierenberg and Hibbs 2000). In Cummins Creek Wilderness, these fires resulted in a mosaic of even-aged stands ranging from 70-120 years in age surrounding remnant old-growth patches with trees $>200$ years (Wimberly and Spies 2001). Historic logging activity affected less than 
$5 \%$ of the wilderness area, mostly along its perimeter. No evidence of fire or harvesting occurs within my study area.

In the absence of fire, wind is the most influential disturbance agent in Oregon's coastal forests and Cummins Creek Wilderness (Harmon et al. 1986; Hadley and Knapp 2011; Knapp and Hadley 2012). The old-growth conditions and high sensitivity to wind disturbance (Hadley and Knapp submitted) in the lower reach of Cummins Creek make it an ideal location to analyze understory succession and diversity in response to the structural legacies created by windsnap and uprooting. 


\section{METHODS}

Field Methods

My field methods consisted of vegetation surveys for 20 uprooted or wind-snapped log sites located in the Cummins Creek study area. All surveyed sites were opportunistically sampled and determined by accessibility. Each site included two substrates: log surface and forest floor. Species, tree diameter at breast height $(1.4 \mathrm{~m})$, log length, orientation (i.e., direction of tree fall relative to stump or rootwad), and log type (snapped or uprooted, as indicated by the presence of a stump or rootwad, respectively) were recorded for all logs. Log decay class was assigned using the log decomposition system established by Maser et al. (1988) (Table 2). Species identification for nine logs was unachievable because of their advanced stages of decay and lack of visible bark. All identified logs were either Sitka spruce or western hemlock. The narrow valley and dense canopy of the study area prohibited the collection of accurate GPS positions for all sites with the available receivers. 
Table 2. Characterization of decay class of fallen trees in the Pacific Northwest (From: Maser et al. 1988).

\begin{tabular}{|c|c|c|c|c|c|}
\hline \multirow[b]{3}{*}{ Log Qualities } & \multicolumn{5}{|c|}{ Decay class } \\
\hline & \multicolumn{2}{|l|}{ Recent } & \multirow[b]{2}{*}{3} & \multirow[b]{2}{*}{4} & \multirow{2}{*}{$\begin{array}{l}\text { Old } \\
5\end{array}$} \\
\hline & 1 & 2 & & & \\
\hline Bark: & Intact & Intact & Trace & Absent & Absent \\
\hline Twigs $>3 \mathrm{~cm}$ : & Present & Absent & Absent & Absent & Absent \\
\hline Texture: & Intact & $\begin{array}{l}\text { Intact to partly } \\
\text { soft }\end{array}$ & $\begin{array}{l}\text { Hard, large } \\
\text { pieces }\end{array}$ & $\begin{array}{l}\text { Small, soft } \\
\text { blocky pieces }\end{array}$ & $\begin{array}{l}\text { Soft and } \\
\text { powdery }\end{array}$ \\
\hline Shape: & Round & Round & Round & Round to oval & Oval \\
\hline Color of wood: & $\begin{array}{l}\text { Original } \\
\text { color }\end{array}$ & Original color & $\begin{array}{l}\text { Original } \\
\text { color to } \\
\text { faded }\end{array}$ & $\begin{array}{l}\text { Light brown } \\
\text { to reddish } \\
\text { brown }\end{array}$ & $\begin{array}{l}\text { Red brown to } \\
\text { dark brown }\end{array}$ \\
\hline $\begin{array}{l}\text { Portion of tree } \\
\text { on ground: }\end{array}$ & $\begin{array}{l}\text { Elevated on } \\
\text { support } \\
\text { points }\end{array}$ & $\begin{array}{l}\text { Elevated on } \\
\text { support points } \\
\text { but sagging } \\
\text { slightly }\end{array}$ & $\begin{array}{l}\text { Tree } \\
\text { sagging } \\
\text { near ground }\end{array}$ & $\begin{array}{l}\text { All of tree on } \\
\text { ground }\end{array}$ & $\begin{array}{l}\text { All of tree on } \\
\text { ground }\end{array}$ \\
\hline $\begin{array}{l}\text { Invading } \\
\text { roots: }\end{array}$ & None & None & In sapwood & In heartwood & In heartwood \\
\hline
\end{tabular}




\section{Vegetation Sampling}

Understory vegetation on each log surface was sampled using $0.5 \mathrm{~m}^{2}$ rectangular quadrats placed at $5 \mathrm{~m}$ intervals along the length of the log, for a total of 2-8 plots per log (Figure 5). Paired forest-floor plots of identical size were positioned $2 \mathrm{~m}$ away from each log plot, on a randomly chosen side (i.e., right or left). I chose a 2 meter distance between quadrat pairs to eliminate log influence within forest floor quadrats. Quadrat placements were adjusted to avoid Sitka spruce or western hemlock trees ( $>4 \mathrm{~cm} \mathrm{DBH}$ and $>1.4 \mathrm{~m}$ tall) growing on the substrates. A total of $103 \log$ and 103 forest floor plots were sampled. 


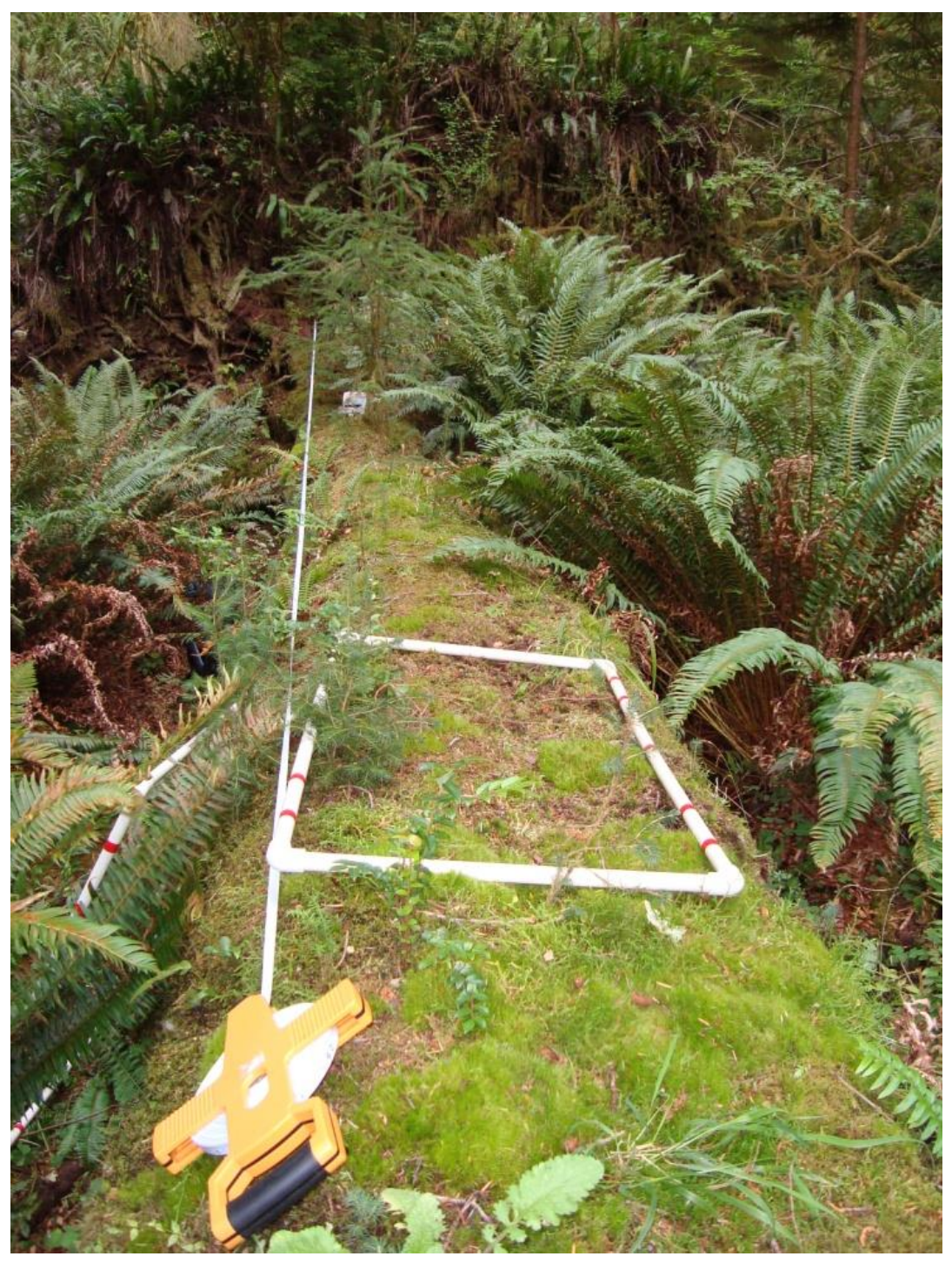

Figure 5. Quadrat sampling on log surface. Photo by: Shannon McDonald.

Visual estimations of percent aerial cover were recorded for each species present in sample quadrats using a modified version of Daubenmire's (1959) cover classification system (Table 3). Percent cover class is a commonly employed vegetative sampling method used to quickly estimate biomass and community dominance (Elzinga et al. 
1998). This method equalizes the contribution from species that are large but few with those that are small and abundant. A cover class of "1" was assigned only if a species had 1-5\% canopy cover, instead of 0$5 \%$ canopy coverage indicated by Daubenmire's scheme. This modification facilitated species richness counts within plots. No attempt was made to identify individual bryophyte species; all moss and liverwort species were pooled and assigned one cover class value per plot. A cover class was assigned for tree seedlings $(<1.4 \mathrm{~m}$ tall) and saplings $(\geq 1.4 \mathrm{~m}$ tall but $<4 \mathrm{~cm} \mathrm{DBH}$ ) encountered within plots. Species need not have been rooted within the plot to have a canopy coverage value. I also conducted a complete species survey of vascular plants rooted within the woody substrate for each of the 20 logs.

Table 3. Daubenmire (1959) Cover Classifications by Ranges of Percent Cover (Modified).

\begin{tabular}{ccc}
$\begin{array}{c}\text { Cover } \\
\text { Class }\end{array}$ & $\begin{array}{c}\text { Range of } \\
\text { Coverage } \\
(\%)\end{array}$ & $\begin{array}{c}\text { Midpoint } \\
\text { of Range } \\
(\%)\end{array}$ \\
\hline 1 & $01-05$ & 3 \\
2 & $06-25$ & 15.5 \\
3 & $26-50$ & 37.5 \\
4 & $51-75$ & 62.5 \\
5 & $76-95$ & 85 \\
6 & $96-100$ & 97.5
\end{tabular}




\section{Data Analysis}

Community composition and diversity data were analyzed across scales using a nested format to accommodate the hierarchical nature of my research objectives (Figure 6). Several analytical techniques were repeated at different hierarchical levels. Exploratory methods were used to discern both the substrate effect (log vs. ground) on community composition and micro-successional pathways on logs. Temporal patterns of community composition were investigated using a space-fortime substitution, where data were compared across logs of varying stages of decay. Log decay class was used as a proxy for time since tree fall to facilitate my examination of succession pathways, competitive interaction, and change in understory composition throughout the decomposition process. Before my analyses I converted cover class rankings (ordinal data) collected during vegetation sampling to their midpoint cover percentages (Table 3) for each species in all quadrats (Daubenmire 1959). Midpoint percentage values were used for all subsequent analysis. 


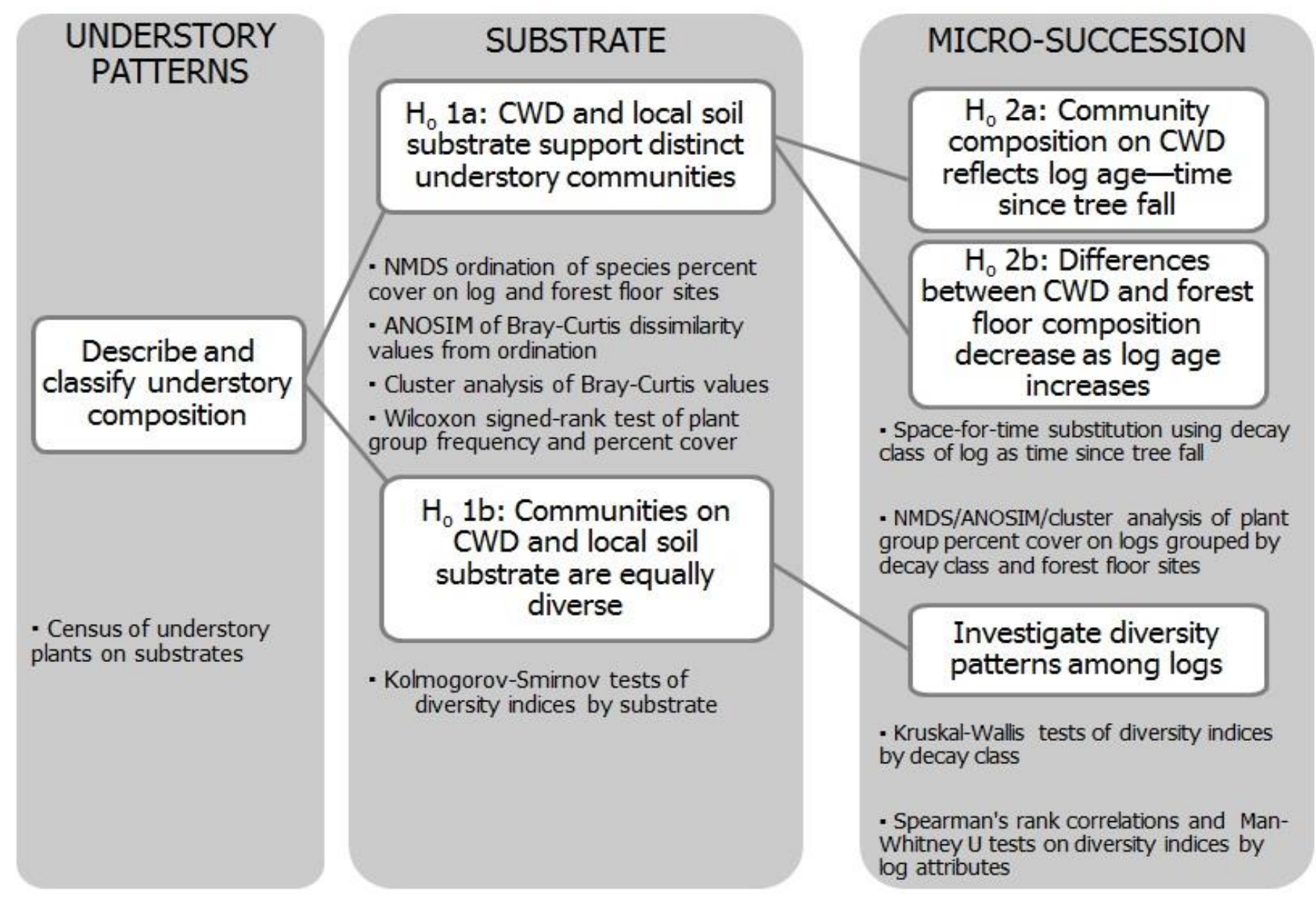

Figure 6. Methods and research objectives. Hypothesis and objectives are presented in white text bubbles with their corresponding methods listed below. Objectives are hierarchical (general to specific) from left to right. 


\section{Community Composition}

I investigated substrate affinities by comparing mean percent cover, mean plot frequency, and mean site frequency of individual species and plant groups between the forest floor and logs. Plant groups were organized according to growth habits and phenology. Groups include shrubs and seedlings (short-statured with woody stems), graminoids (grasses and sedges), ferns (vascular plants that reproduce via spores), and forbs (herbaceous flowering plants). Mean percent cover and plot frequency were calculated by averaging quadrat values within a site then across sites for both substrates. Site frequency corresponds to the percentage of site occurrence, i.e., the presence or absence of a species in the series of samples for each site. Wilcoxon signed-rank tests, a non-parametric counterpart of the paired t-test, were used to test significant differences in the above measures for plant groups by substrate type.

Non-Metric Multidimensional Scaling. Unconstrained, non-metric multidimensional scaling (NMDS) ordinations were used to explore and compare community assemblages relative to substrate type and decay class. NMDS ordinations graphically represent community relationships by preserving the rank order of between-sample dissimilarities in species 
composition in the rank order of distances in ordination space (Clarke 1993). All ordinations were plotted in 3 dimensions using Bray-Curtis distance matrices with package VEGAN in the R Project for Statistical Computing (Oksanen 2007). Matrices are derived from pair-wise comparisons of all sites using the relative abundance of each species, the total number of species that are unique to either site, and the total species richness over the two sites. Bray-Curtis dissimilarity, a Manhattan type distance measure (limited to a grid cell path), is commonly employed in ordinations of species data where local absences are common as joint absences do not affect output results. The maximum value (1) indicates there are no shared species between sites (Oksanen 2007). Bray-Curtis dissimilarity coefficients were calculated for all pair-wise comparisons of sites using percent cover data averaged across quadrats within each paired site.

Sites are plotted in NMDS ordination space using the distance matrix, providing a spatial representation of the data where sites that are closer together are more similar. The goodness-of-fit between the ordination distances and dissimilarity matrix is assessed with a stress value (S). Lower stress values indicate increasing agreement between rank-orders of ordination and matrix distances. $\mathrm{S}^{2}=1-\mathrm{R}^{2}$, where $\mathrm{R}$ is the correlation, or linear fit, between the observed dissimilarities and ordination distances (Oksanen 2007). 
NMDS axes can be interpreted as environmental gradients across sites using Spearman's rank or multiple regressions to assess the strength of the relationships between environmental variables and site locations in ordination space. Measurements of environmental variables were beyond the scope of this study thus explanatory variables can only be inferred. Plotting the NMDS in 3 dimensions often increases goodness-of-fit (McCune et al. 2002) but warrants careful interpretation of the 3 dimensional ordination depicted in 2-dimensional space. In this case, there is a $3^{\text {rd }}$ "invisible" axis coming forward in addition to the horizontal and vertical axes.

Analyses of Group Variability. I used analyses of similarities (ANOSIM) to assess the statistical significance of differences in species assemblages relative to substrate type and decay class. ANOSIM, a nonparametric multivariate analysis of variance, compares within group dissimilarity to between group dissimilarity. It ranks the dissimilarity matrix used in the NMDS and computes its statistic $\mathrm{R}$ as the difference between mean ranks of within group and between group dissimilarities. The R-statistic is scaled from -1 to +1 , whereby increasing positive values indicate increasing difference between groups (Oksanen 2007). Significance $(p<0.05)$ is determined with a random bootstrapping procedure (999 permutations) that calculates a distribution of $\mathrm{R}$ under 
the null hypothesis of no difference between groups; calculated $\mathrm{R}$ statistics are compared to the null distribution. Values $<1$ are rare in community data and a significant $\mathrm{R}$ statistic greater than 0 indicates that groups differ in community composition (Clarke 1993).

When datasets include more than two groups and the global ANOSIM indicates a significant difference among groups, I repeated the test on each pair of groups. Clarke (1993) suggests a minimum sample size $(n=10)$ to reliably detect small changes in community composition. I ran global and pair-wise ANOSIM tests on sample plots grouped by decay class to correct for the small sample sizes of sites grouped by decay class. All global and paired ANOSIM tests were based on Bray-Curtis dissimilarity values calculated with package VEGAN in the R Project for Statistical Computing.

Cluster Analysis. I performed cluster analyses to identity group structure in the dataset. This analysis was employed to complement and compare results with the NMDS ordinations. An unsupervised clustering method - an approach used in the absence of a priori knowledge of groups - was used to objectively support or weaken my hypotheses that community composition reflects substrate type (i.e., forest floor, log, and decay class of log). Like NMDS, cluster analysis is not equipped to confirm or invalidate specific hypotheses. Rather, it is designed for 
exploratory research that summarizes and investigates complex, multivariate data.

I used the Cluster package in the R Project for Statistical Computing (Maechler et al. 2012) for these analyses. Specifically, I employed function "agnes" (agglomerative nesting), a hierarchical technique based on the principle that similarities between objects increase as their distance decreases. This method begins with a single observation and successively merges the nearest (most similar) observation until one large cluster remains containing all observations (Rousseeuw and Kaufman1990), resulting in a hierarchy of clusters that combine with each other at specified distances. Similarities between observations were determined using the Bray-Curtis dissimilarity matrix derived from the percent cover data. I used Ward's minimum variance method for merging observations. Ward's differs from other linkage methods in that it seeks to minimize the variance (i.e., error sum of squares) of Bray-Curtis dissimilarities within clusters instead of using the actual distance metric in a nearest or farthest neighbor technique (Rousseeuw and Kaufman1990). I chose this method to compliment the NMDS ordinations where the distance between observations is visually easy to assess.

Results are illustrated with a dendrogram where the $\mathrm{Y}$ axis depicts the distance at which clusters merge and the observations are grouped 
along the $\mathrm{X}$ axis. Individual clusters were defined as having a maximum within group distance of $<1.0$. The "agnes" clustering analysis produces an agglomerative coefficient (AC) that measures the degree of clustering structure in the dataset. The $\mathrm{AC}$ is the average of all $1-d(i)$, where $d(i)$ is the dissimilarity of each observation $i$ to the first cluster it is merged with divided by the dissimilarity of the final merger in the analysis. An AC value close to 1 denotes a strong clustering structure while values near 0 represent weak structure or a single large group.

Species Diversity

Community diversity was characterized by comparing of measures of community structure among the substrates. These measures include: 1) mean site and plot richness, 2) mean plot percent cover, 3) species evenness, 4) the Shannon-Wiener diversity index, and 5) Simpson's diversity index. Species evenness was calculated using Pielou's J, a measure of the relative abundance assigned to each species. The Shannon-Wiener diversity index $(\mathrm{H})$ is a measure of the uncertainty in predicting the species of a randomly selected individual, incorporating both evenness and richness. Simpson's diversity index (D) represents the probability that two individuals randomly selected from a sample will belong to the same species. For this metric I used the inverse, 1-D, to 
resolve the counterintuitive meaning of $\mathrm{D}$, where values closer to 0 represent higher diversity. Lastly, I calculated the Sørenson's similarity index, a measure of species overlap, between substrates where 0 indicates complete distinction and 1 indicates $100 \%$ overlap.

Differences in the above metrics between log and ground sites were assessed using non-parametric two-sample Kolmogorov-Smirnov tests (Figure 6). I employed non-parametric Kruskal-Wallis tests to evaluate differences among sites grouped by decay class (Figure 6). This approach employs a null hypothesis that the probability of a randomly chosen observation from one group is greater than a random observation from another group equals 0.5 . Spearman's rank correlations were used to investigate the relationships between diversity and log diameter (DBH) while Mann-Whitney U tests, similar to the Kruskal-Wallis, were employed for the categorical attributes of orientation, species, and presence/absence of rootwad. 


\section{RESULTS}

\section{Community Composition between Substrates}

A total of 47 species were encountered on the two substrate types. Six species were found only on logs, eight were found only on the forest floor, and 33 were found on both substrates (Table 4). Wilcoxon signedrank tests showed significant differences between substrates in forb percent cover $(p<0.01)$ and frequency $(p<0.001)$ and seedling and shrub percent cover $(\mathrm{p}<0.01)$ and frequency $(\mathrm{p}<0.01)$. Shrubs and seedlings had higher percent cover and frequency on logs while forbs had higher percent cover and frequency on ground sites (Table 5). Ferns had higher total percent cover and frequency on ground sites but paired differences for individual species were not statistically significant ( $p>.05)$.

Of the 33 species occurring on both substrates, most exhibited a preference for either logs or forest floor. Paired differences for the mean frequency (Figure 7) and mean percent cover for shrubs and seedlings show this plant group's preference for logs (Figure 8). The forb group's affinity for forest floor substrates is indicated by its negative paired differences in mean frequency (Figure 7) and mean percent cover (Figure 8). I found no group substrate affinities for ferns and graminoids with individual species exhibiting different preferences (Figures 7 and 8). 
Table 4. Individual species and plant group averages by substrate type. Statistics include mean percent cover, mean frequency (percentage of plot occurrence), and site frequency (percentage of sites where found, $\mathrm{n}=40$ ) for all species sampled. Group values in bold indicate significant differences between substrate types (Wilcoxon signed-rank test, $\mathrm{p}<0.01$ ).

\begin{tabular}{|c|c|c|c|c|c|c|c|}
\hline & \multirow{2}{*}{$\begin{array}{l}\text { Plant Group } \\
\text { Species }\end{array}$} & \multicolumn{3}{|c|}{ Log } & \multicolumn{3}{|c|}{ Ground } \\
\hline & & $\begin{array}{c}\% \\
\text { Cover }\end{array}$ & $\begin{array}{l}\text { Fre- } \\
\text { quency }\end{array}$ & $\begin{array}{c}\text { Site } \\
\text { Fre- } \\
\text { quency }\end{array}$ & $\begin{array}{c}\% \\
\text { Cover }\end{array}$ & $\begin{array}{l}\text { Fre- } \\
\text { quency }\end{array}$ & $\begin{array}{c}\text { Site } \\
\text { Fre- } \\
\text { quency }\end{array}$ \\
\hline \multirow[t]{2}{*}{ MOSS } & Bryophytes & 66.69 & 100 & 100 & 31.9 & 95.5 & 100 \\
\hline & Ferns & & & & & & \\
\hline ADPE & Adiantum pedatum & 0.03 & 1.25 & 5 & $\ldots$ & $\ldots$ & 0 \\
\hline ATFI & Athyrium filix-femina & 1.16 & 6.36 & 25 & 2.64 & 18.54 & 40 \\
\hline BLSP & Blechnum spicant & 3.5 & 17.49 & 50 & 9.48 & 38.04 & 75 \\
\hline EQAR & Equisetum arvense & 0.57 & 1.88 & 10 & 2.98 & 9 & 20 \\
\hline DREX & Dryopteris expansa & 5.48 & 34.99 & 70 & 2.69 & 19.98 & 60 \\
\hline POGL & Polypodium glycyrrhiza & 0.53 & 9.63 & 35 & $\ldots$ & $\ldots$ & 0 \\
\hline POMU & Polystichum munitum & 20.47 & 48.65 & 80 & 48.8 & 71.74 & 90 \\
\hline \multirow[t]{3}{*}{ POSC } & Polypodium scouleri & 0.02 & 0.63 & 5 & $\ldots$ & $\ldots$ & 0 \\
\hline & Total & 31.75 & 120.86 & & 66.59 & 157.3 & \\
\hline & Forbs & & & & & & \\
\hline AQFO & Aquilegia formosa & $\ldots$ & $\ldots$ & 0 & 0.08 & 3 & 5 \\
\hline BOEL & Boykinia elata & $\ldots$ & $\ldots$ & 0 & 0.02 & 0.71 & 5 \\
\hline CHGL & $\begin{array}{l}\text { Chrysosplenium } \\
\text { glecho-maefolium }\end{array}$ & 0.19 & 1.25 & 5 & 0.18 & 3.3 & 15 \\
\hline CLSI & Claytonia sibrica & 4.57 & 43.08 & 95 & 3.65 & 40.27 & 75 \\
\hline DIHO & Disporum hookeri & $\ldots$ & $\ldots$ & 0 & 0.11 & 0.71 & 5 \\
\hline DIPU & Digitalis purpurea & $\ldots$ & $\ldots$ & 0 & 0.94 & 2.5 & 5 \\
\hline GATR & Galium triflorum & 0.55 & 6.63 & 25 & 0.88 & 12.51 & 40 \\
\hline HYRA & Hypochaeris radicata & $\ldots$ & $\ldots$ & 0 & 0.03 & 1 & 5 \\
\hline LYAM & Lysichiton americanum & 0.19 & 1.25 & 5 & 4.16 & 12.85 & 40 \\
\hline LYUN & Lycopus uniflorus & 0.29 & 5 & 10 & 0.78 & 14.09 & 40 \\
\hline MADI & $\begin{array}{l}\text { Maianthemum } \\
\text { dilatatum }\end{array}$ & 0.09 & 3.51 & 20 & 1 & 15.89 & 35 \\
\hline MAOR & Marah oreganus & 0.1 & 0.63 & 5 & 0.02 & 0.63 & 5 \\
\hline OESA & Oenanthe sarmentosa & 0.68 & 7.5 & 10 & 1.21 & 12.59 & 30 \\
\hline OXOR & Oxalis oregana & 1.84 & 13.84 & 35 & 15.35 & 40.8 & 70 \\
\hline PRVU & Prunella vulgaris & 0.03 & 1.25 & 5 & 0.09 & 3.75 & 10 \\
\hline RARE & Ranunculus repens & 0.06 & 2.5 & 5 & 2.01 & 7.5 & 15 \\
\hline
\end{tabular}




\begin{tabular}{|c|c|c|c|c|c|c|c|}
\hline SEJA & Senecio jacobaea & 0.97 & 6.25 & 15 & 0.19 & 2.25 & 10 \\
\hline SMRA & Smilacina racemosa & $\ldots$ & $\ldots$ & 0 & 0.03 & 1 & 5 \\
\hline STCO & Stachys cooleyae & 0.78 & 6.25 & 15 & 5.75 & 34.27 & 70 \\
\hline STCR & Stellaria crispa & 0.3 & 5.63 & 20 & 0.16 & 6.55 & 35 \\
\hline TRCE & Trisetum cernuum & 1.21 & 14.5 & 35 & 5.62 & 24.14 & 50 \\
\hline TOME & Tolmiea menziesii & 1.83 & 12.46 & 30 & 7.01 & 18.76 & 45 \\
\hline TROV & Trillium ovatum & $\ldots$ & $\ldots$ & 0 & 0.16 & 1 & 5 \\
\hline UNP1 & Unidentified plant & 0.02 & 0.63 & 5 & 0.98 & 4.13 & 15 \\
\hline VEAM & Veronica americana & $\ldots$ & $\ldots$ & 0 & 0.21 & 1.88 & 10 \\
\hline \multirow[t]{3}{*}{ VIGL } & Viola glabella & 0.03 & 1.25 & 5 & 0.11 & 4.38 & 15 \\
\hline & Total & 13.72 & 133.39 & & 50.70 & 270.45 & \\
\hline & Graminoids & & & & & & \\
\hline CALE & Carex leptopoda & 2.04 & 21.53 & 70 & 1.29 & 17.06 & 45 \\
\hline \multirow[t]{3}{*}{ SCMI } & Scirpus microcarpus & 0.19 & 1.25 & 5 & 3.53 & 9.96 & 35 \\
\hline & Total & 2.23 & 22.78 & & 4.82 & 27.02 & \\
\hline & Shrubs and Seedlings & & & & & & \\
\hline ALRU & Alnus rubra & 0.13 & 5 & 15 & $\ldots$ & $\ldots$ & 0 \\
\hline GASH & Gaultheria shallon & 5.22 & 19.88 & 40 & 0.86 & 4.75 & 15 \\
\hline MEFE & Menziesia ferruginea & 7.66 & 36.82 & 75 & 0.3 & 5.64 & 25 \\
\hline OECE & Oemleria cerasiformis & 0.02 & 0.63 & 5 & $\ldots$ & $\ldots$ & 0 \\
\hline PISI & Picea sitchensis & 9.12 & 44.38 & 90 & 0.26 & 1.63 & 10 \\
\hline RUSP & Rubus spectabilis & 1.24 & 13.1 & 55 & 1.31 & 13.97 & 55 \\
\hline SARA & Sambucus racemosa & 1.74 & 5.96 & 25 & 0.56 & 3.75 & 20 \\
\hline TSHE & Tsuga heterophylla & 3.19 & 37.92 & 90 & $\ldots$ & $\ldots$ & 0 \\
\hline VAOV & Vaccinium ovatum & 16.74 & 48.9 & 85 & 4.19 & 9.13 & 40 \\
\hline \multirow[t]{2}{*}{ VAPA } & Vaccinium parvifolium & 5.63 & 34.86 & 60 & 1.33 & 9.27 & 25 \\
\hline & Total & 50.69 & 247.45 & & 8.80 & 48.14 & \\
\hline
\end{tabular}




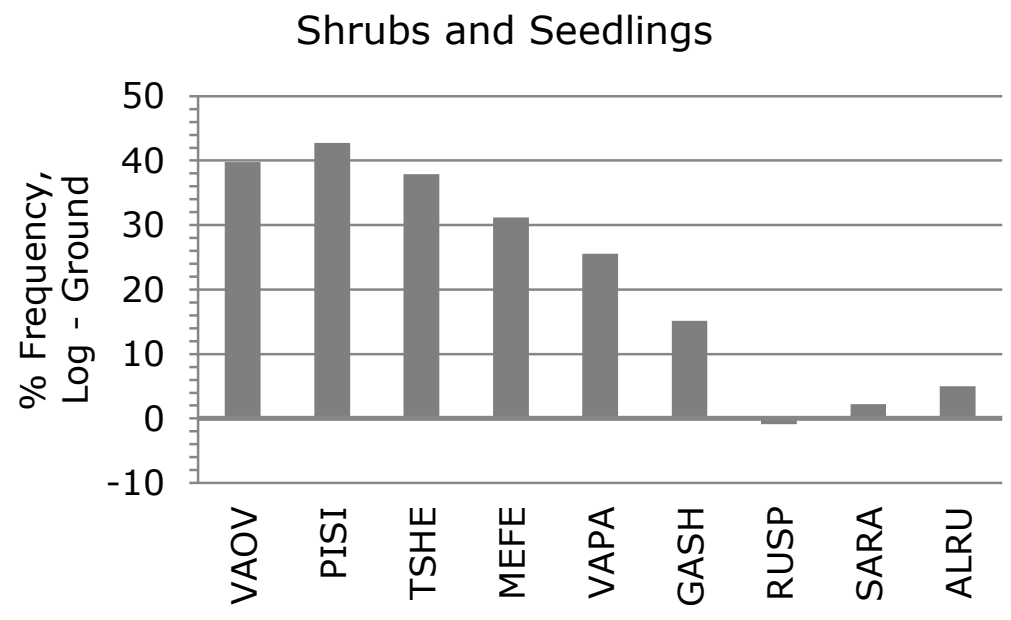

Forbs

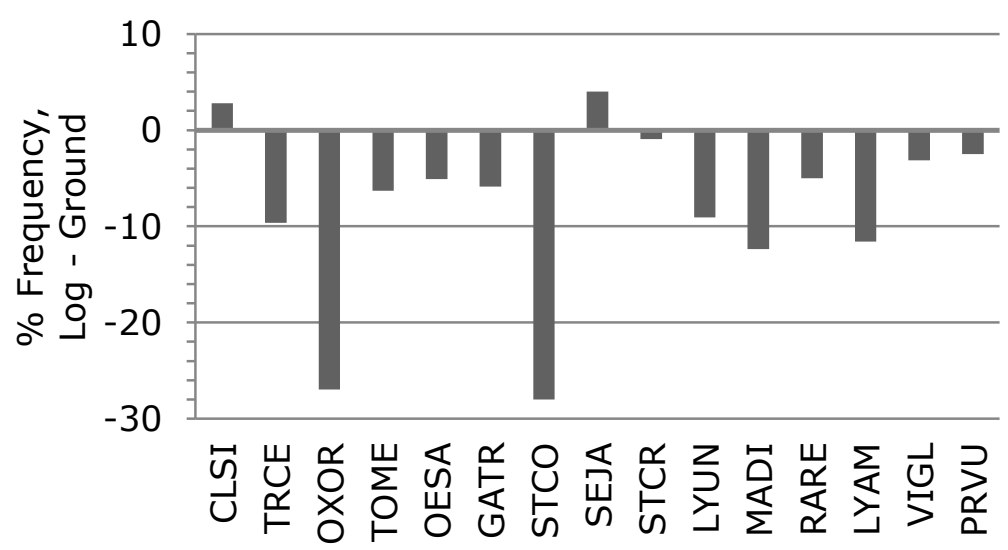

Ferns and Graminoids

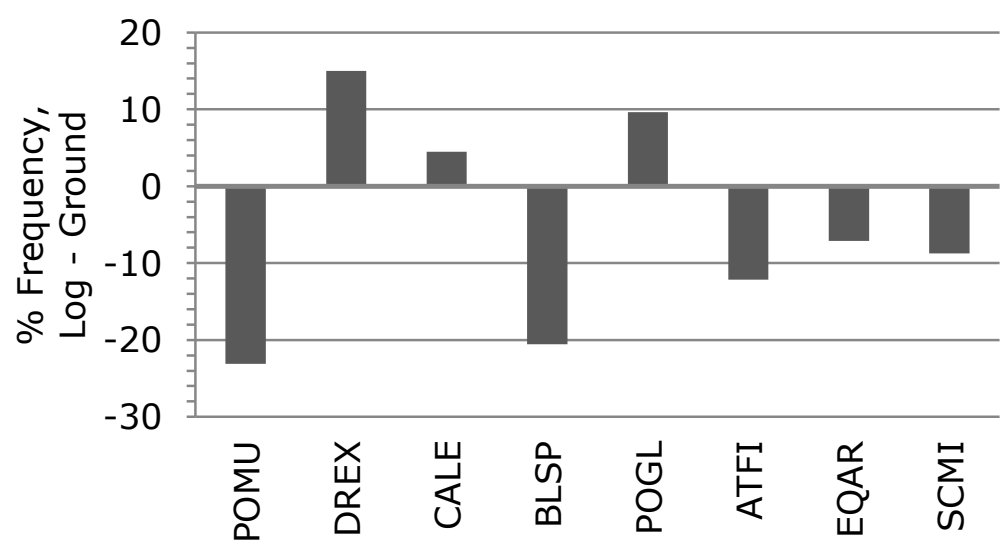

Figure 7. Frequency charts showing paired differences in average frequency for species with $\geq 5 \%$ mean frequency. Positive values $(>0)$ represent higher frequencies on logs; negative values $(<0)$ represent higher frequencies on ground. See Table 4 for key to species' codes. 

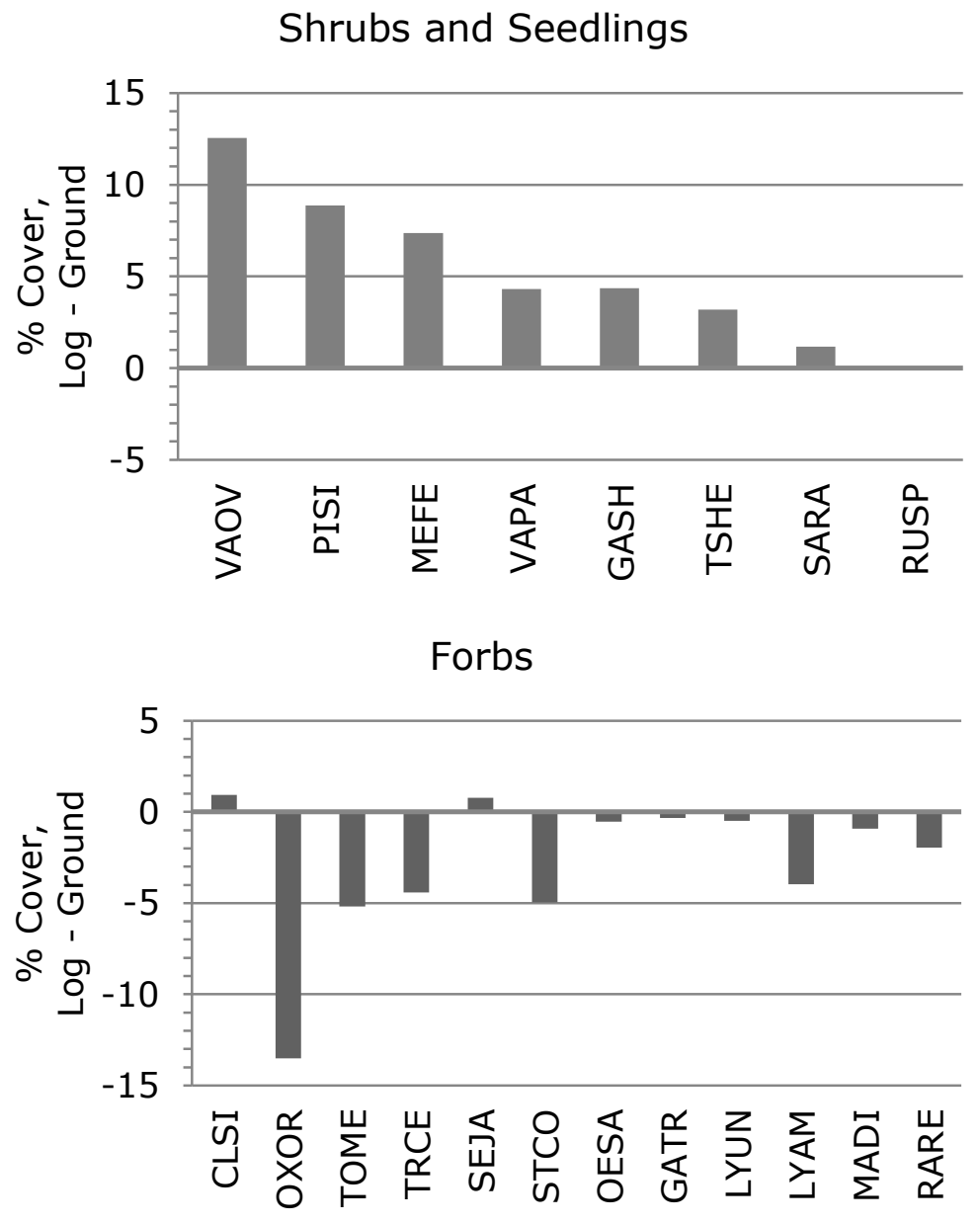

Ferns and Graminoids

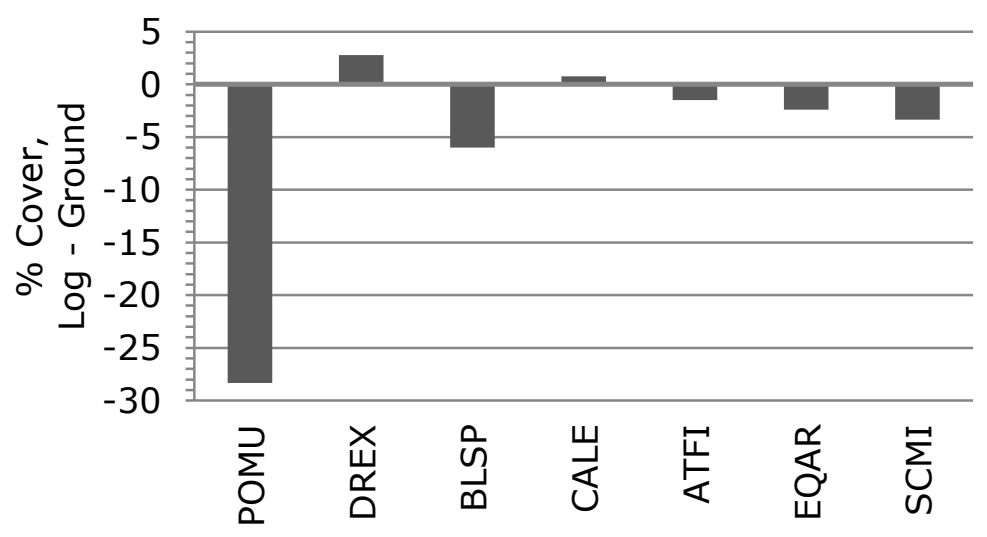

Figure 8. Percent cover charts showing paired differences in average percent cover for species with $\geq 1 \%$ total cover. Positive values $(>0)$ represent higher percent cover on logs; negative values $(<0)$ represent higher percent cover on ground. See Table 4 for key to species' codes. 


\section{Ordination of Understory Composition by Substrate}

NMDS ordinations revealed clear differences in species composition on log versus ground sites (Figure 9) with one exception (site 12), where the log and ground pair are adjacent in ordination space. Site 3 has the highest dissimilarity between pairs with a smaller substrate effect on species composition among the remaining sites. Site numbers do not necessarily reflect on-the-ground spatial proximity (e.g., sites 1 and 2 cannot be assumed to be closer in proximity to each other than sites 1 and 5).

Log sites are concentrated along the lower third of the $\mathrm{X}$ axis with a high abundance of shrubs and seedlings such as evergreen huckleberry (VAOV), false azalea (MEFE), salal (GASH), Sitka spruce (PISI), and western hemlock (TSHE) (Figure 9). Ground sites are dispersed along both the $\mathrm{X}$ and $\mathrm{Y}$ axes. Results from a global ANOSIM test show between substrate Bray-Curtis dissimilarities have significantly higher mean rank-orders than within substrate dissimilarities (Rstatistic $=0.51, \mathrm{p}=0.001)$ indicating a significant difference in species assemblages between sites grouped by substrate (Figure 10). 

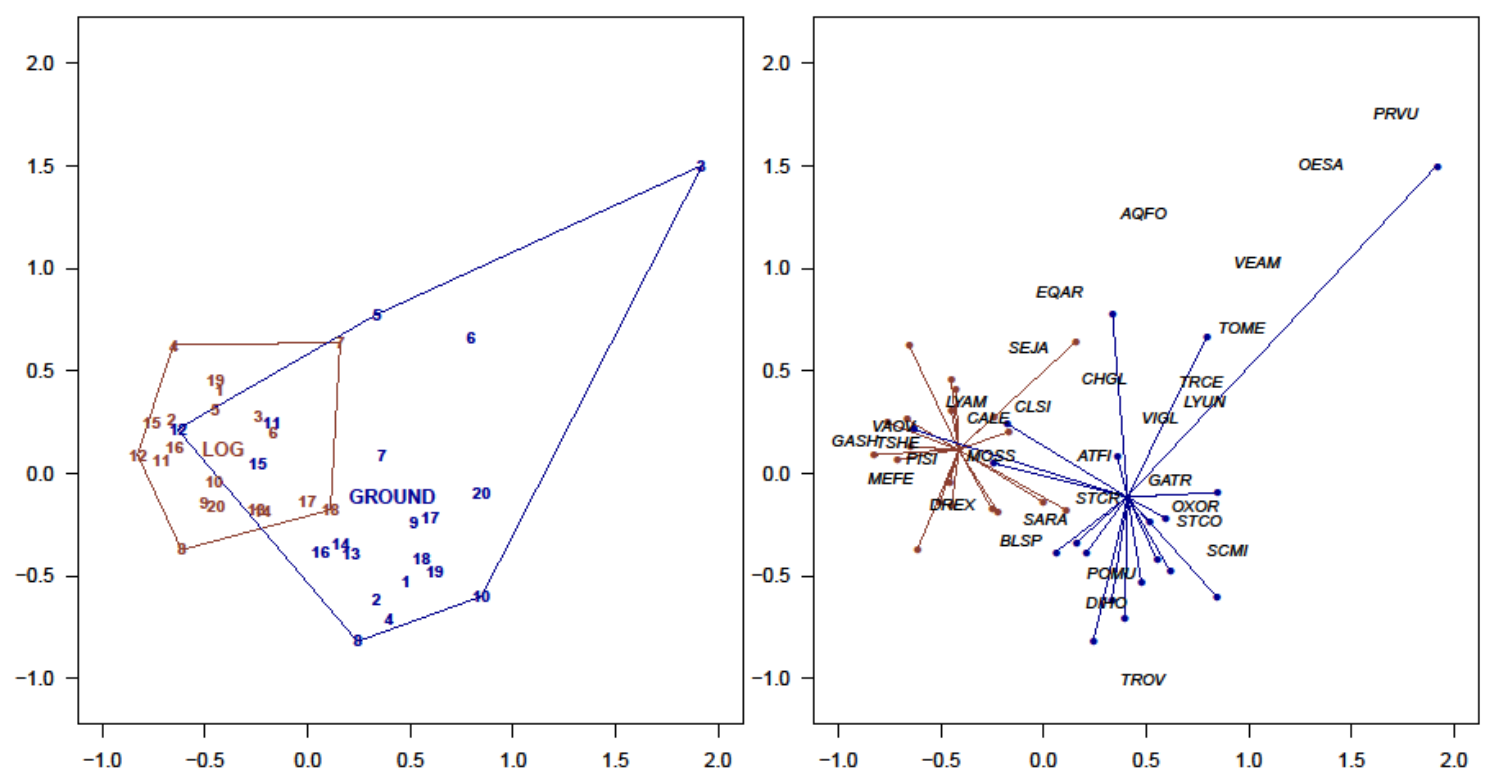

Figure 9. NMDS ordination of study sites $(n=40)$, plotted in three dimensions using Bray-Curtis dissimilarity of percent cover data (stress $=0.194)$. Units are raw axes scores marking the distance, with a linear relationship to dissimilarity, between sites. Blue site numbers represent ground sites and brown numbers represent log sites; identical numbers indicate site pairs. Sites within each substrate are connected by lines originating from the centroid of sites grouped by substrate. Species' codes (Table 4) plotted on the right graph represent species scores (i.e., the abundance weighted centroids of sites where sampled). 


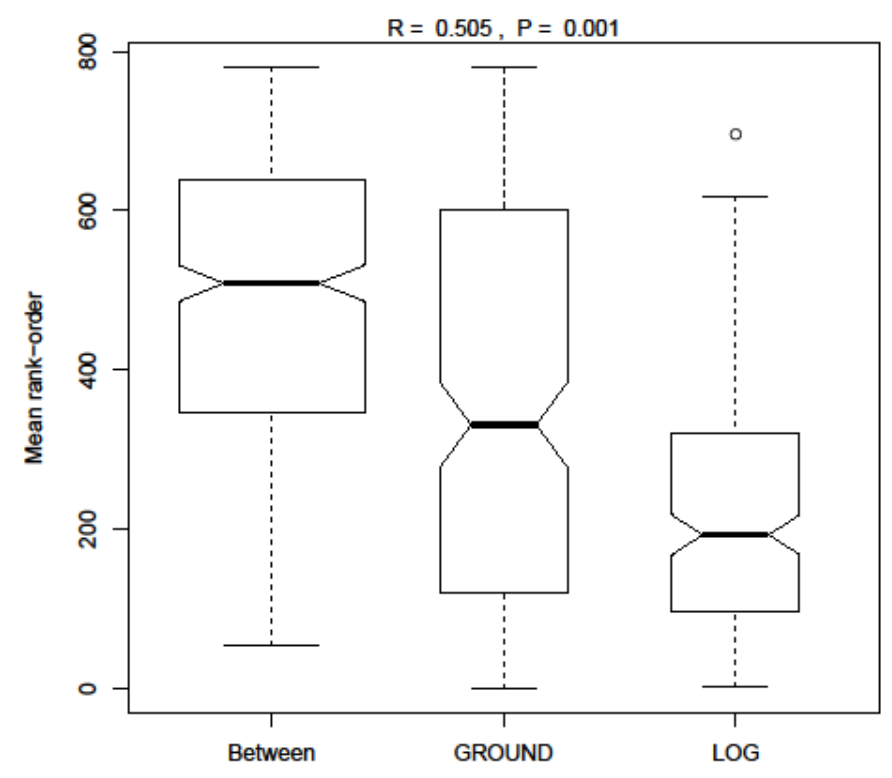

Figure 10. Notched boxplots of ANOSIM's mean rank-ordering of pairwise Bray-Curtis dissimilarity values within substrate groups and between substrate groups. Notches represent the 95\% confidence interval of the medians; non-overlapping notches indicate a significant difference. Box widths are proportional to sample size. The dissimilarities between log and ground sites have higher mean ranks than the dissimilarities within either group. An R-statistic of 0.51 indicates that the groups differ in community composition ( $\mathrm{p}=0.001)$. 
Cluster Analysis of Community Composition

Cluster analysis of Bray-Curtis dissimilarities illustrates the compositional differences by substrate type (Figure 11). An agglomerative coefficient (AC) of 0.84 indicates a high degree of clustering structure in the data corresponding to substrate type (Figure 11). Two of the four clusters consist chiefly of log sites and two are comprised of ground sites. Four sites - ground sites within log groups - were misclassified. Three of these misclassified sites would form a discrete cluster if the maximum within group distance were reduced to $\sim 0.75$, allowing groups to have single observations.

The cluster analysis created two sub-groups with different dominant species within each substrate type (Figure 12). The smallest group, with three ground sites, is united by the occurrence of forbs common among hydric plots. The second cluster of ground sites shares more prevalent forest floor ferns and forbs. The largest log cluster, including three ground sites, is dominated by the seedlings and shrubs. The remaining centermost group (Figure 12) consists mainly of log sites containing species that were more common on ground sites or species that were found with similar frequency on both substrates (Figure 7). 

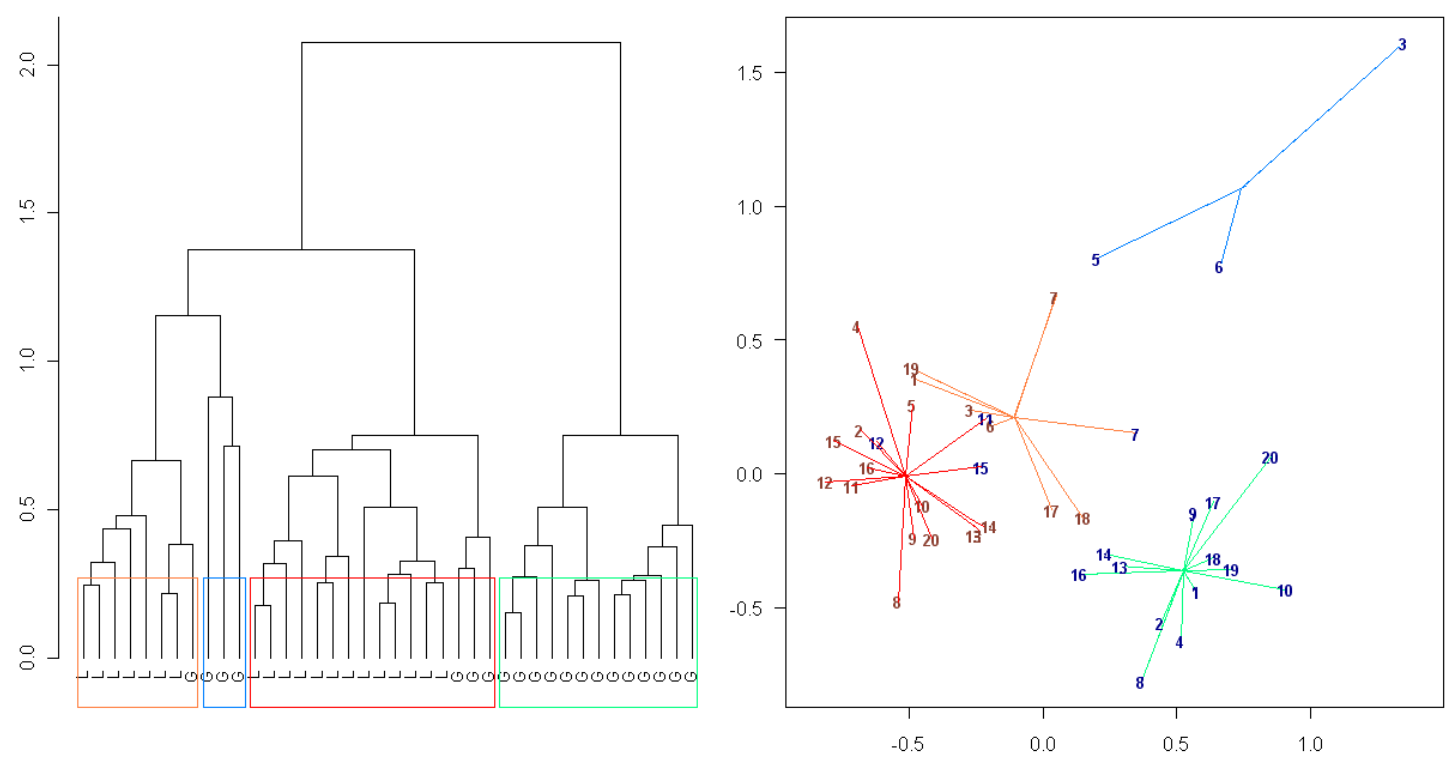

Figure 11. Dendrogram of sites labeled by substrate type $(\mathrm{L}=\log$ or $\mathrm{G}=$ ground) with 4 clusters highlighted (left). Ward's minimum variance method used for agglomerative clustering of Bray-Curtis dissimilarity values. The Y-axis depicts the distance at which observations and clusters are merged. Cluster groups are defined with a maximum internal distance of 1.0. An agglomerative coefficient of 0.84 indicates a high degree of clustering structure in the dataset. The NMDS ordination of sites (Figure 9) shows individual clusters connected by lines originating from their centroid (right). 


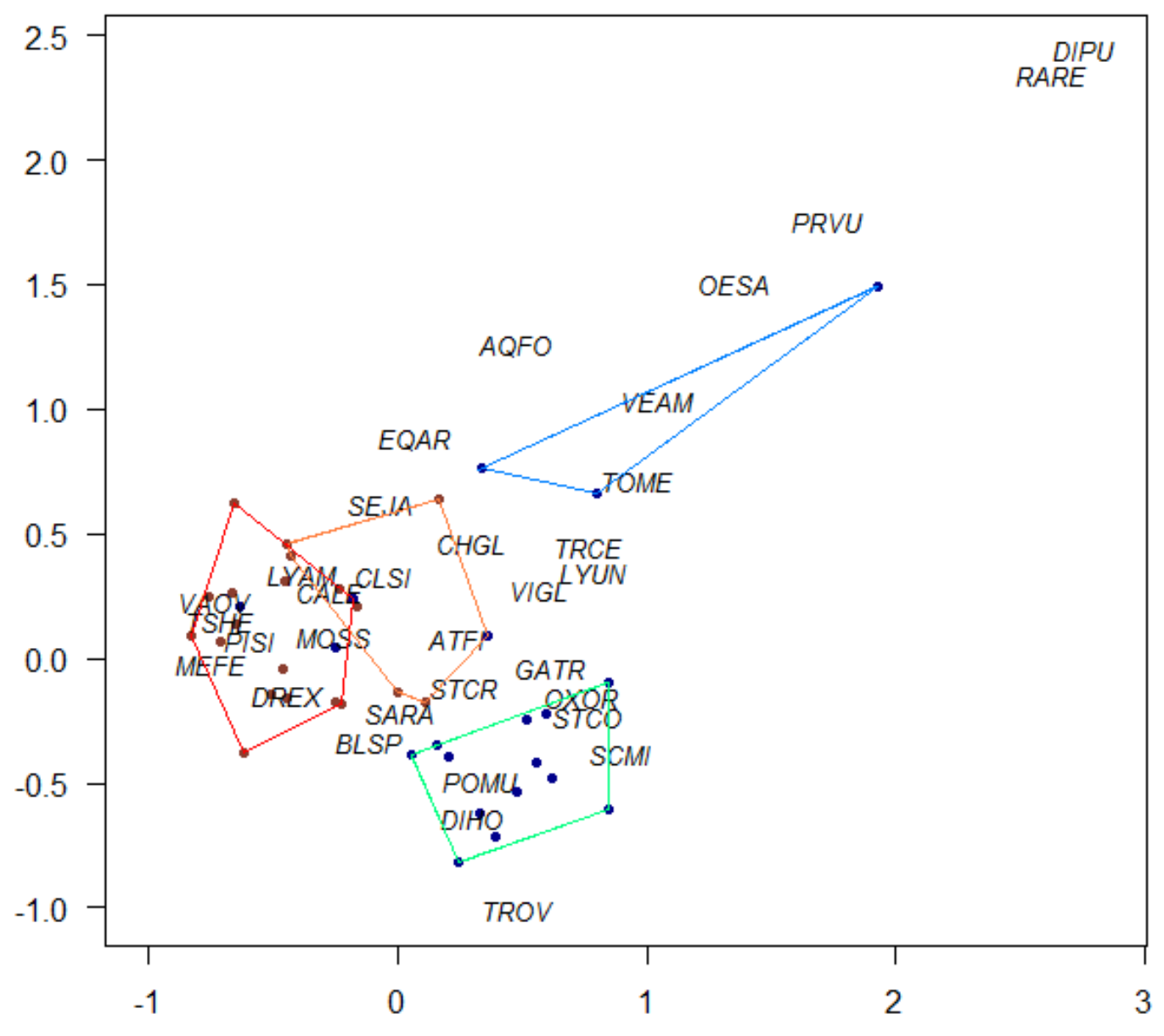

Figure 12. Combined depiction of NMDS of sites, species scores, and cluster hulls for $\log$ and forest floor understory species. Cluster hulls are color coded to match the results from the cluster analysis of sites (Figure $11)$. 


\section{Diversity Differences among Substrates}

Ground sites have slightly higher Simpson's and Shannon-Weiner diversity indices and species evenness values (Table 5). The Sørensen's Similarity Index for log and ground sites (0.83) indicates moderately-high species overlap. A general trend of increasing Simpson's 1-D, Shannon's $\mathrm{H}$, and evenness with increasing decay is evident among the indices grouped by log class (Table 5), although site richness, plot richness, and plot percent cover are lowest for logs of decay class 6 .

Kolmogorov-Smirnov tests showed no significant differences between $\log$ and ground sites for any diversity measure. Similarly, Kruskal-Wallis tests indicate no significant differences in diversity among decay classes. The small and uneven sample sizes among decay classes may impede the detection of significant differences in Simpson's 1-D, Shannon's H, and Pielou's J values. 
Table 5. Diversity measures by substrate (log, ground, and log decay class). Indices calculated for individual sites and averaged among substrates. Plot richness and percent cover are mean values by site. No statistically significant differences were found between log and ground substrates (Kolmogorov-Smirnov tests) or among decay classes (KruskalWallis tests).

\begin{tabular}{rccccccc} 
Substrate & $\mathrm{n}=$ & $\begin{array}{c}\text { Simpson's } \\
\text { 1-D }\end{array}$ & $\begin{array}{c}\text { Shannon's } \\
\mathrm{H}\end{array}$ & Pielou's J & $\begin{array}{c}\text { Site } \\
\text { Richness }\end{array}$ & $\begin{array}{c}\text { Plot } \\
\text { Richness }\end{array}$ & $\begin{array}{c}\text { Plot \% } \\
\text { Cover }\end{array}$ \\
\hline Ground & 20 & 0.74 & 1.72 & 0.70 & 13.2 & 6.0 & 162.8 \\
Log & 20 & 0.72 & 1.70 & 0.66 & 13.4 & 6.2 & 163.7 \\
3 & 6 & 0.66 & 1.57 & 0.60 & 13.8 & 5.6 & 157.3 \\
4 & 4 & 0.74 & 1.75 & 0.67 & 14.0 & 7.2 & 172.9 \\
5 & 8 & 0.73 & 1.74 & 0.68 & 13.4 & 6.6 & 170.7 \\
6 & 2 & 0.79 & 1.85 & 0.77 & 11.0 & 5.0 & 136.5
\end{tabular}




\section{Community Composition Patterns on CWD}

Cluster Analysis of Decay Classes

Cluster analysis results indicate an absence of compositional groupings among log sites by decay class (Figure 13) and clustering identical to the substrate analysis (Figure 11). The two clusters representing log sites (with four ground site misclassifications) both contain log of decay classes 3-5. These results indicate no distinct changes in community composition over time.
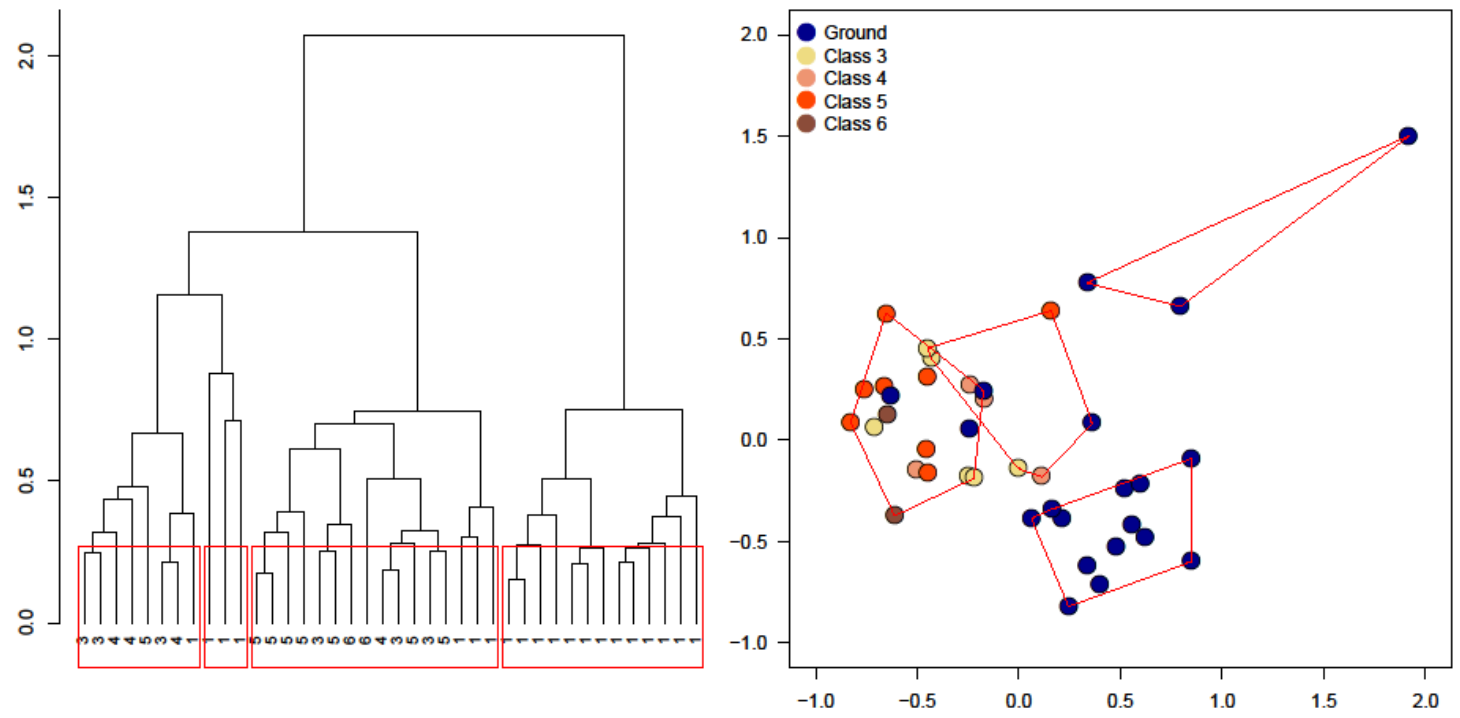

Figure 13. Dendrogram of sites labeled by decay class ( $1=$ Ground, $3-6=1$ log class) with 4 clusters highlighted (left). Ward's minimum variance method used for agglomerative clustering with Bray-Curtis dissimilarity values. The Y-axis depicts the distance at which observations and clusters are merged. Cluster groups are determined by an internal distance break of 1.0. An agglomerative coefficient of 0.84 indicates a high degree of clustering structure in the dataset, although clusters are not defined by decay class. The NMDS ordination of sites (Figure 9) shows the clusters as hulls (right). 


\section{Plant Group Ordinations by Substrate Class}

NMDS bubble plots of the three main plant groups (i.e., ferns, forbs, and shrubs and seedlings) further illustrate substrate and decay class preferences. Among plant groups, shrubs and seedlings have the least presence on ground sites and the greatest presence on log sites (Figures 14-16). The combined relative percent cover of shrub and seedlings increases with the decay class of logs (Figure 14). The fern group has the highest percent cover values on the ground sites (Figures 14-16). One exception is the forest floor outlier in the upper right corner of the ordination with the greatest percent cover in the forb group (Figure 16). This site is dominated by non-natives Ranunculus repens and Digitalis purpurea (Figure 9). Unlike forbs and shrubs, ferns are wellrepresented on both substrate types but exhibit a preference for ground sites (Figure 15). The ordinations do not expose any clear relationships between percent cover and decay class for ferns and forbs with the exception of the two highest decay class log sites having low percent cover values for both plant groups. Appendix A includes bubble plots of the most common individual species within each plant group. 


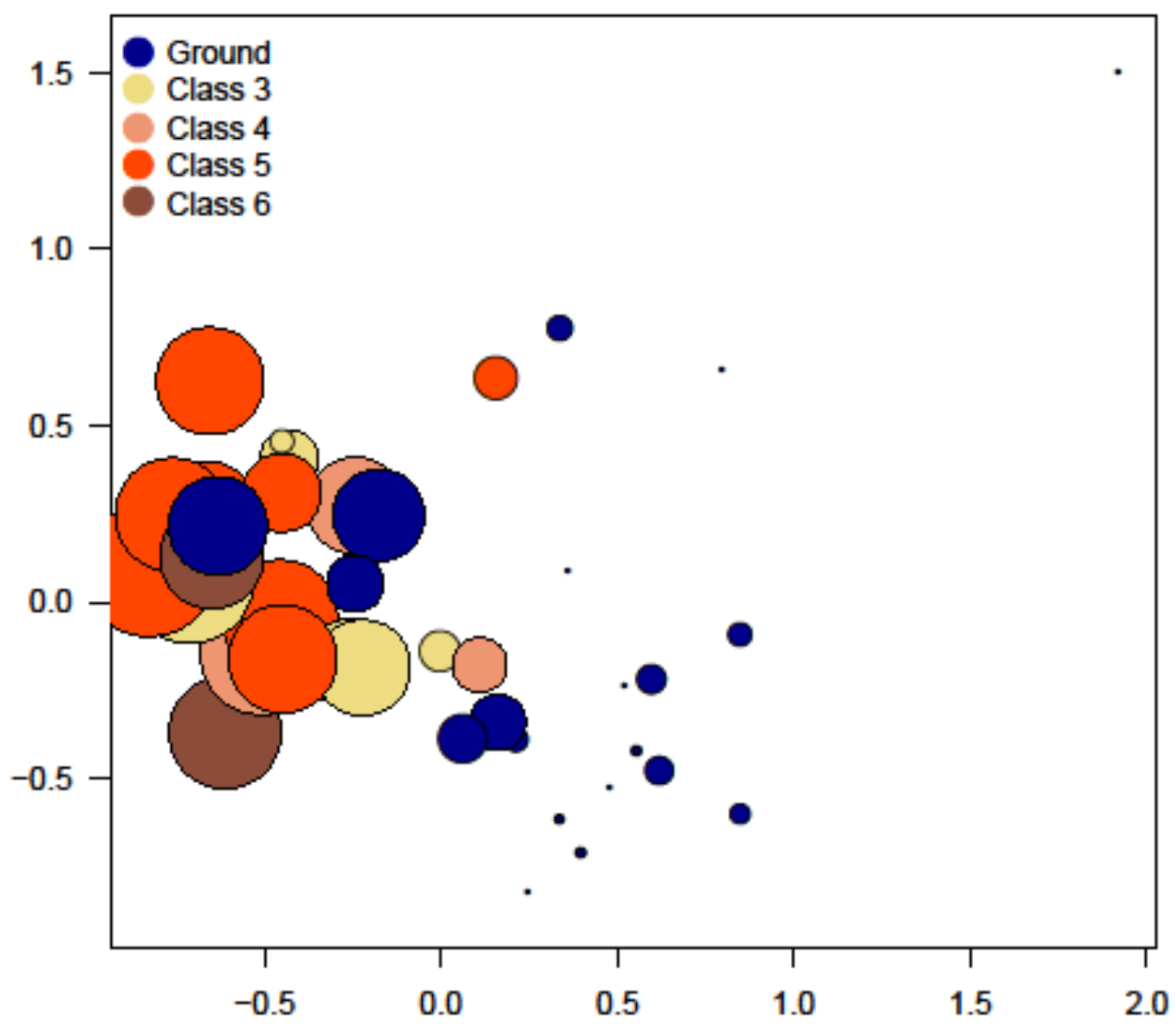

Figure 14. NMDS bubble plots of the shrub and seedling group. Circle areas are proportional to the combined relative percent cover of seedling and shrub species for each site. Colors represent different substrate types (ground vs. log) and log decay classes. 


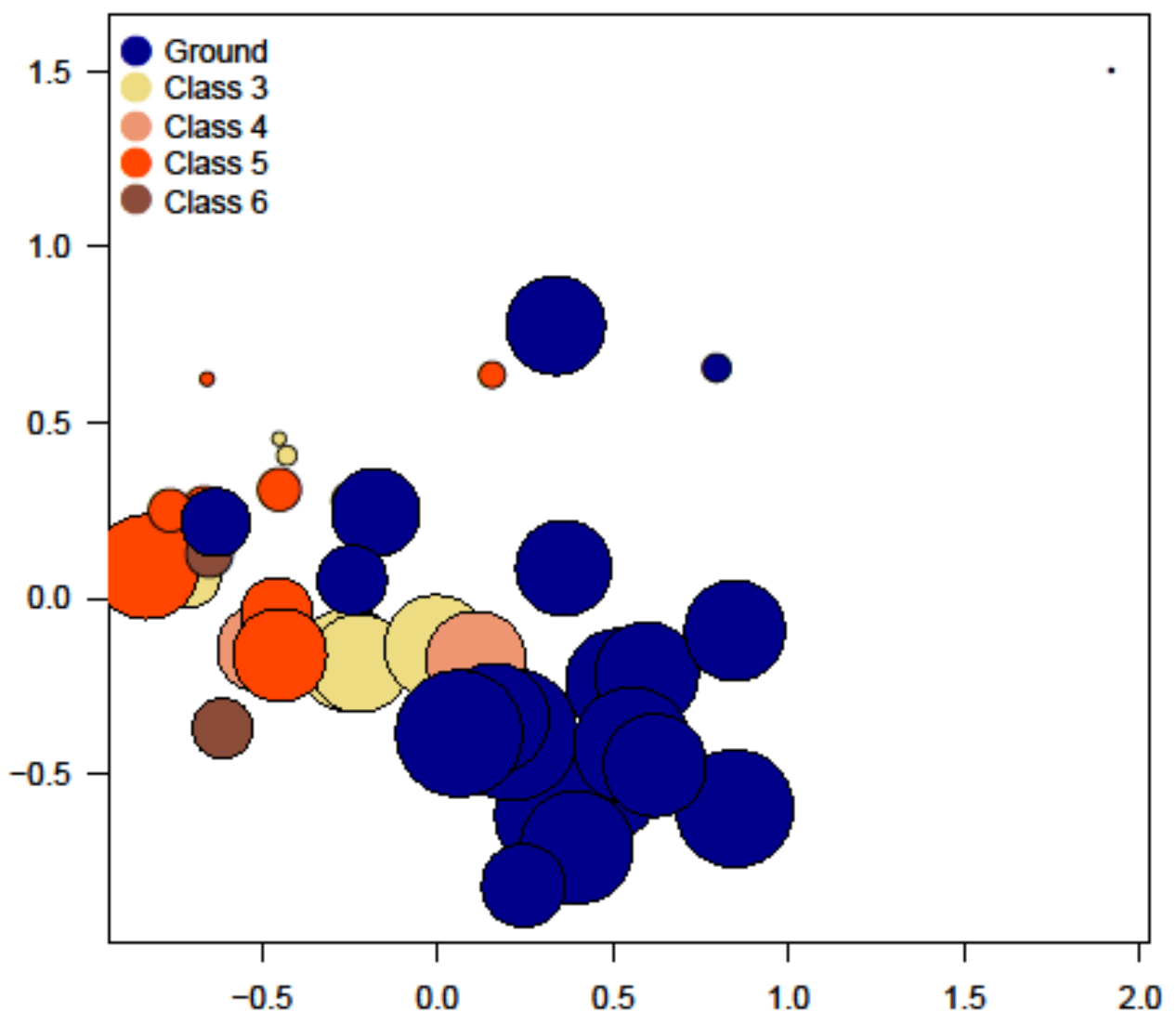

Figure 15. NMDS bubble plots of the fern group. Circle areas are proportional to the total relative percent cover of fern species for each site and color coded by substrate. 


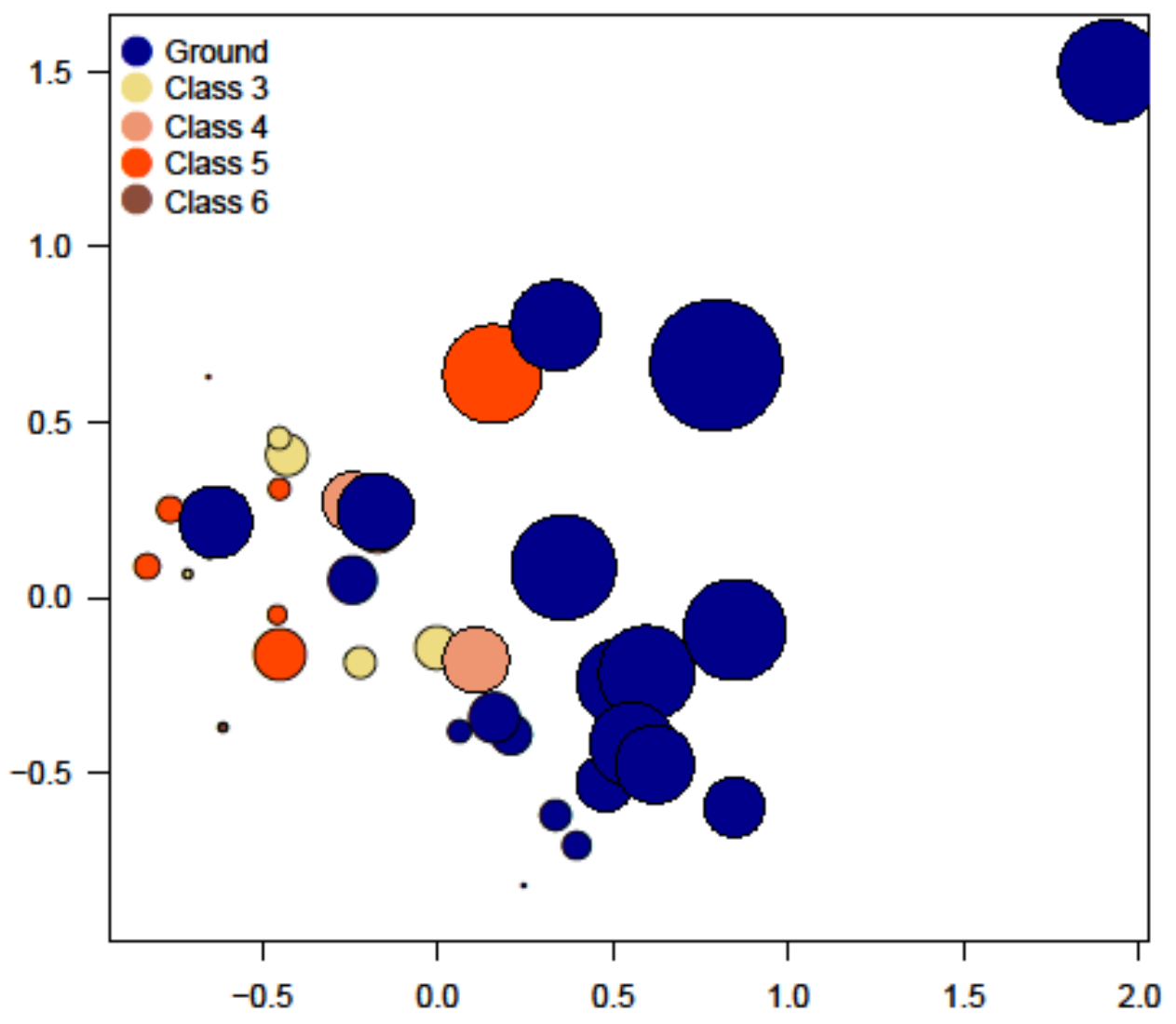

Figure 16. NMDS bubble plots of the forb group. Circle areas are proportional to the total relative percent cover of all forb species within each site and color coded by substrate. 


\section{ANOSIM by Substrate Class}

Results from a global ANOSIM of Bray-Curtis dissimilarity values reveal small but significant differences in species assemblages present among forest floor sites $(n=20)$, and logs of decay classes $3,(n=6), 4$ $(\mathrm{n}=4), 5(\mathrm{n}=8)$, and $6(\mathrm{n}=2)(\mathrm{R}-\mathrm{statistic}=0.24, \mathrm{p}<0.005)$. A plot-level global ANOSIM test indicates a significant difference in species assemblages between forest floor plots $(n=103)$, decay class $3(n=40)$, class $4(n=17)$, class $5(n=38)$, and class $6(n=8)(R-$ statistic $=0.15$, $\mathrm{p}<0.001$ ) (Figure 17). Significant differences were found in pair-wise tests of species assemblages between plots on the forest floor and those on decay class 3 (R-statistic $=0.13, \mathrm{p}<0.05)$, forest floor plots and class 5 plots (R-statistic $=0.30, \mathrm{p}<0.01)$, and between class 3 and class 5 plots (Rstatistic $=0.09, \mathrm{p}<0.01)($ Table 6).

Significant R-statistics between substrate classes were low compared to the binary ANOSIM for log versus ground sites (Figure 10, R-statistic $=0.51)$ indicating that substrate type is the main driver of compositional differences, with substrate class (i.e., change over time) being a secondary factor. Although R-statistics are low among substrate classes, these differences are more distinct in the bubble plots of individual species (Appendix A) than in the above cluster analysis or the bubble plots of plant groups. 


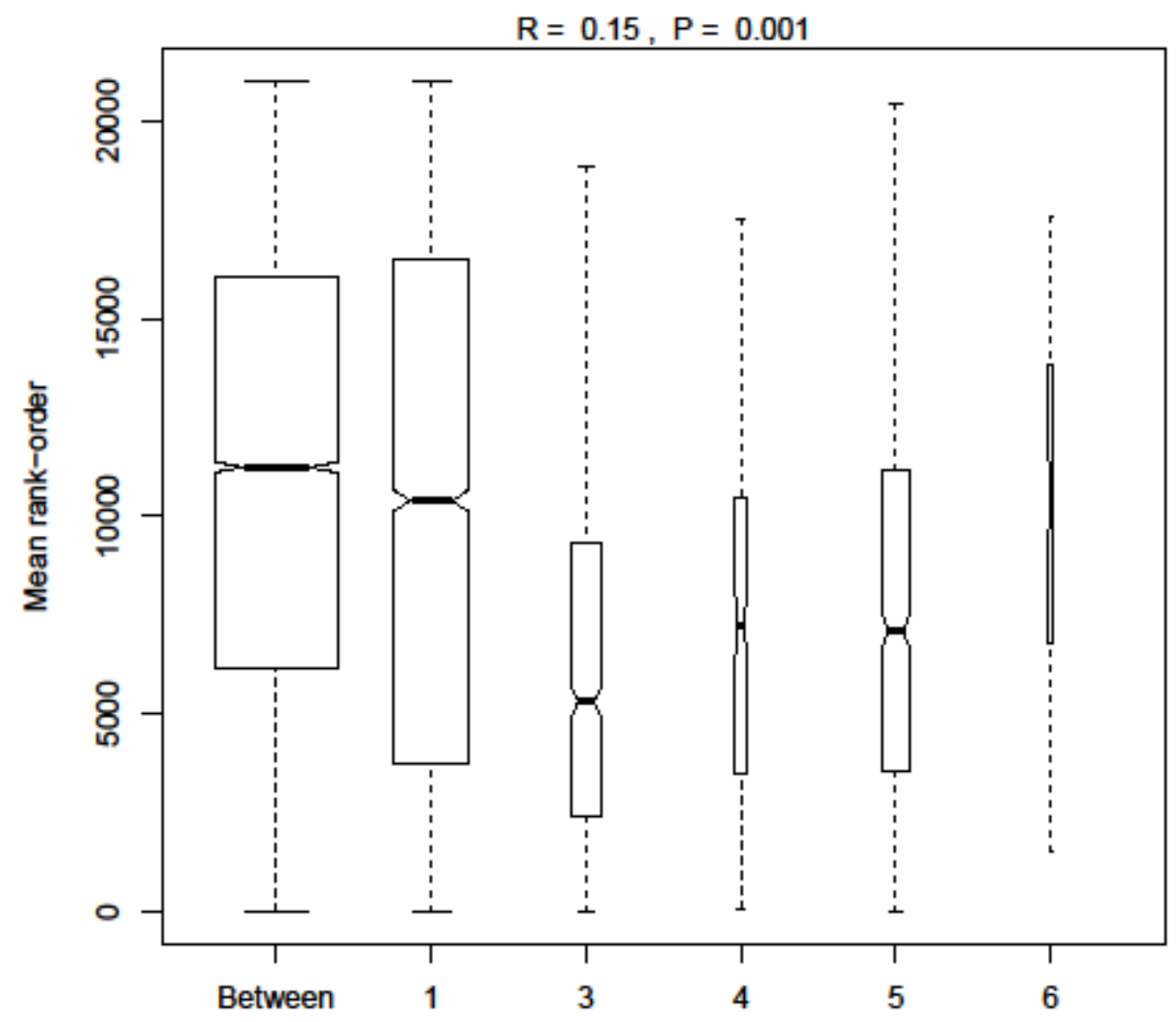

Figure 17. Notched boxplots of ANOSIM's mean rank-ordering of BrayCurtis dissimilarity values of plots within substrate groups and between substrate groups. Substrate groups are labeled along the $\mathrm{X}$-axis, with " 1 " = forest floor plots. Notches represent the $95 \%$ confidence interval of the medians; non-overlapping notches indicate a significant difference. Boxplot widths are proportional to sample size. The dissimilarities between substrate groups have higher mean ranks than the dissimilarities within groups, with the exception of class 6 . An R-statistic of 0.15 indicates a small difference in community composition among groups $(\mathrm{p}<0.001)$. 
Table 6. Pair-wise ANOSIM tests among plots grouped by substrate. Higher values denote greater pair-wise difference in species assemblages where an R-statistic $=1$ indicates complete dissimilarity between groups and an R-statistic $=0$ indicates random grouping of observations (i.e., no difference). Values based on mean ranks of within group and between group Bray-Curtis distance. Bold R-statistics are significant after Bonferroni corrections $(\mathrm{p}<0.05)$.

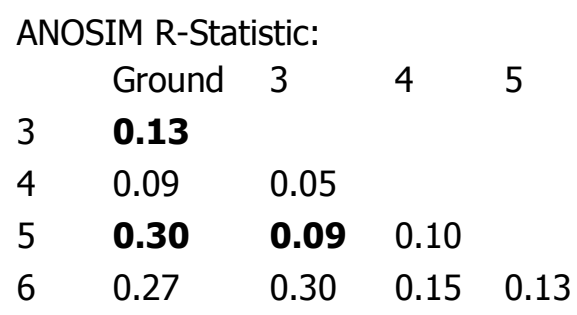

Bonferroni-Corrected Significance Values:

$\begin{array}{lllll} & \text { Ground } & 3 & 4 & 5 \\ 3 & 0.04 & & & \\ 4 & 1.20 & 2.17 & & \\ 5 & 0.01 & 0.01 & 0.78 & \\ 6 & 0.17 & 0.10 & 0.65 & 1.14\end{array}$

Non-Decay Class Factors Affecting Understory Composition on Logs

In addition to decay class, I measured and analyzed several additional log attributes (Table 7 ) to evaluate their possible influence on species richness and diversity among log sites. No relationships were found between $\mathrm{DBH}$ and richness, mean plot richness, mean percent cover, or any other diversity index. Of the categorical variables, only log 
orientation (i.e., northern versus southern direction of tree fall) was associated with diversity indices. Logs pointing north had higher mean plot richness (Mann-Whitney $\mathrm{U}, \mathrm{p}<0.05)$ and total richness (MannWhitney U, p<0.05).

Table 7. Attributes of sampled logs. Total richness includes sides and buttresses of logs and some species may not be represented in plots. $\mathrm{Y} / \mathrm{N}$ indicates presence/absence of rootwad as evidence of uprooting. Orientation specifies direction of tree fall relative to the stump or rootwad. X indicates log was too decomposed for identification. Species' codes follow Table 4.

\begin{tabular}{cccccccccc} 
Log & $\begin{array}{c}\text { Decay } \\
\text { Class }\end{array}$ & DBH & $\begin{array}{c}\text { Length } \\
(\mathrm{m})\end{array}$ & Rootwad & $\begin{array}{c}\text { Orien- } \\
\text { tation }\end{array}$ & Species & Richness & $\begin{array}{c}\text { Mean Plot } \\
\text { Richness }\end{array}$ & $\begin{array}{c}\text { Mean Plot } \\
\text { Cover (\%) }\end{array}$ \\
\hline 1 & 3 & 127 & 42 & Y & S & PISI & 23 & 3.8 & 106 \\
11 & 3 & 82 & 39 & Y & S & TSHE & 15 & 7 & 194 \\
13 & 3 & 60 & 31.5 & N & S & PISI & 13 & 6.4 & 188 \\
14 & 3 & 58 & 31.5 & Y & SE & TSHE & 15 & 5.9 & 188 \\
17 & 3 & 105 & 44 & Y & SE & TSHE & 22 & 6.8 & 176 \\
19 & 3 & 86 & 13 & Y & S & TSHE & 7 & 3.5 & 92 \\
3 & 4 & 50 & 4 & N & N & X & 28 & 10 & 164 \\
6 & 4 & 72 & 17.4 & N & NW & PISI & 24 & 6.5 & 134 \\
9 & 4 & 98 & 31.9 & Y & S & X & 17 & 6.8 & 182 \\
18 & 4 & 54 & 17 & N & SE & X & 11 & 5.5 & 211 \\
2 & 5 & 100 & 21.3 & N & S & PISI & 14 & 5 & 135 \\
4 & 5 & 47 & 14.1 & N & SE & X & 9 & 3.3 & 118 \\
5 & 5 & 50 & 20.8 & N & NE & X & 15 & 5.2 & 106 \\
7 & 5 & 63 & 14.1 & N & NW & X & 28 & 10.5 & 182 \\
10 & 5 & 115 & 44 & N & S & X & 17 & 6.1 & 176 \\
12 & 5 & 155 & 15 & N & N & PISI & 17 & 8.5 & 245 \\
15 & 5 & 100 & 14 & N & SE & TSHE & 10 & 7 & 169 \\
20 & 5 & 105 & 26 & N & SW & PISI & 14 & 6.8 & 235 \\
8 & 6 & 68 & 10 & N & S & X & 11 & 4.7 & 120 \\
16 & 6 & 120 & 23.5 & N & SW & X & 12 & 5.2 & 153
\end{tabular}




\section{DISCUSSION}

\section{Substrate Community Composition}

The majority of Cummins Creek understory species exhibit substrate preferences (Figures 7-8) and 30\% of species were restricted to a single substrate (Table 4). Similar to Kennedy and Quinn's (2001) findings on the Olympic Peninsula, the log and forest floor substrates at Cummins Creek support distinct plant communities having similar levels of species richness, evenness, and diversity (Figures 9-12; Table 5). These results differ from those reported by Six and Halpern (2008) for the western Cascades where ca. $70 \%$ of species demonstrate substrate preferences but have fewer obligate species-substrate relationships.

The similar number of affinities for ground and log substrates also differs from the 3:1 preference for soil substrates reported for the western Cascades (Six and Halpern 2008). This difference appears related to the desiccation of moss mats that inhibits root establishment on logs in drier, inland PNW forests (Harmon and Franklin 1989). Six and Halpern (2008) suggest the soil substrate preference is also related to the greater substrate stability of the forest floor not subject to bark sloughing, substrate fragmentation, or dependent upon a tree fall for emplacement. Understory species in the western Cascades may also be adapted to drier 
growing seasons and greater winter snow pack, negating the need for moisture retention provided by CWD.

Coastal conditions at Cummins' Creek may increase the importance of CWD as a substrate and account for its greater share of species' affinities. High CWD levels and input rates increase substrate availability and slower decomposition rates delay wood fragmentation, providing more time for plants to establish and stabilize before disintegration of the substrate. The advantages to soil rooting in drier forest types may thus be minimized at coastal sites characterized by higher forest productivity, larger logs with slower decomposition rates, and more frequent high wind events (Maser and Trappe 1984; Hadley and Knapp submitted).

The dense understory cover (163\%) of the forest floor at Cummins Creek (Table 5) may also contribute to the more even distribution of species preferences between substrates. Six and Halpern (2008) attributed the greater affinities for the forest floor to reduced competition from mosses on logs. The dense understory vegetation at Cummins Creek may eliminate the competitive advantage of establishing on the forest floor demonstrated in other forest types. 


\section{Light Levels and Moisture Gradients}

Differences in community composition between elevated CWD and the forest floor at Cummins Creek appear to be related to differences in light levels and moisture conditions. The role of light levels is indirectly shown by the NMDS species clusters and differences in percent cover data (Figures 14-16; Appendix A). These results are consistent with PNW seedling (Harmon and Franklin 1989) and understory studies (Kennedy and Quinn 2001; Six and Halpern 2008). My NMDS results (Figure 12) also suggest species distributions are consistent with niche differentiation based on resource partitioning by light levels (Appendix A). This pattern is most clear on the forest floor where species are vertically segregated, e.g., low stature, shade-tolerant species like redwood sorrel (OXOR) and Cooley's hedge-nettle (STCO) growing under sword fern (POMU).

Growing-season moisture at Cummins Creek is generally greater on the forest floor than logs (personal observation). Consequently, moisture stress (dry conditions) does not appear to influence understory diversity, unlike inland forests where CWD affects understory composition by mitigating summer moisture deficits (e.g., Harmon and Franklin 1989; Six and Halpern 2008). 
Species diversity and abundance at Cummins Creek do appear to be governed by soil moisture surplus and drainage as suggested by NMDS differences between the forest floor and log sites (Figure 9). The ordination of species scores (Figure 12) and the bubble plots (Appendix A) also suggest the presence of a forest floor moisture gradient as evidenced by increasing hydric species abundance (e.g., Pacific water parsley (OESA), piggy back plant (TOME), self-heal (PRVU), and creeping buttercup (RARE)) along both ordination axes. These results are similar to those presented by Pabst and Spies' (1998) that suggest moisture gradients play a more important role in coastal, riparian sites than in inland PNW forests. Species tolerance to soil saturation, instead of moisture stress (e.g., Harmon and Franklin 1989; Six and Halpern 2008) appears to be an important factor explaining differences in community composition between substrates. Although substrates host similar diversity, compositional differences among forest floor sites appear to reflect the greater heterogeneity of forest floor environmental conditions.

\section{Habitat Diversity}

Similar to other studies (e.g., Beatty 1984; Ulanova 2000; Kennedy and Quinn 2001) (Table 1), my results indicate the structural legacies of canopy disturbance increase forest biodiversity by providing new habitats 
for colonization and creating fine-scale environmental gradients. CWD at Cummins Creek appears to provide refugia for species that might otherwise be out competed or prohibited from establishment on the forest floor (Harmon and Franklin 1989; Kennedy and Quinn 2001).

Frequent hurricane-force windstorms along the central Oregon Coast contribute to a wide range of forest canopy conditions (Hadley and Knapp submitted) resulting in: 1) high accumulations of CWD at Cummins Creek and 2) a heterogeneous understory environment consistent with the conditions outlined by Connell's (1979) intermediate disturbance hypothesis (IDH). Under these conditions, understory species diversity peaks when disturbance levels are neither too high nor too low (Savage et al. 2000). Connell (1979) suggests that this level of disturbance-induced change maintains diversity by interrupting the competitive process, preventing the elimination of inferior competitors, and supporting chance replacements.

Micro-succession on CWD

CWD Decomposition and Vegetation Dynamics

Similar to findings of McCullough (1948), my results indicate a temporal trend of CWD community succession with higher forb, fern, and seedling abundance during the early to intermediate stages of log decay 
followed by the dominance of woody shrubs (Figure 14-16; Appendix A). Contrary to my hypothesis of convergence between forest floor and log communities with decomposition, I found increasing divergence between logs and the forest floor culminating at decay class 5 (Figure 13; Table 6). These results are tentative because of the limited sample size among decay classes and differ from those found in other forest types (i.e., Lee and Sturgess 2001; Kushnevskaya et al. 2007).

Transformation of the physical properties of CWD with decomposition is an important factor driving vascular plant succession on logs (Harmon et al. 1986; Lee and Sturgess 2001; Rambo 2001). Higher forest productivity and rates of input, and the small surface areato-volume ratios and higher proportions of resistant heartwood of large, old-growth logs result in slower decomposition rates and greater accumulations of CWD in coastal PNW forests (Harmon et al. 1986; Edmonds 1991). As such, I hypothesize that the increased spatial and temporal presence of CWD at Cummins Creek raises its status to a fundamental substrate capable of supporting distinct communities on longer time-scales as opposed to its role as a shifting, more temporary host in other forest types.

Facilitative and competitive interactions can also drive microsuccession on CWD (Harmon 1989; Kushnevskaya et al. 2007). For example, the forest floor dominance of sword fern at Cummins Creek 
appears to exclude the establishment of all but the most shade-tolerant species thereby restricting the establishment of less competitive herbs, shrubs, and seedlings to the elevated CWD substrate. Shrub presence on the forest floor is substantial in the absence of sword fern (Appendix A) and shrubs appear better adapted and may out-compete sword fern on CWD.

\section{Micro-Succession and Species Diversity}

Species diversity on CWD appears to increase with log decomposition, reaching peak richness during intermediate stages of decay (Table 5). This stage may be best suited for high species diversity because of favorable physical properties (e.g., increased moisture and litter accumulation) and the duration of substrate exposure (i.e., longer availability for colonization relative to recently fallen logs but prior to the competitive interaction and exclusionary phase) (Harmon 1989; Kushnevskya et al. 2007). This interpretation is supported by the high percent cover on decay class 4 logs (Table 5) with relatively lower percent cover values for plant groups (Figures 14-16) or individual species (Appendix A). My results showing an initial peaking then subsequent decreasing richness during micro-succession are similar to the patterns reported by Kushnevskya et al. (2007) for pooled bryophyte and vascular 
species. When examined separately, Kushnevkaya et al. (2007) found vascular plant richness peaked in the final stage of micro-succession. Lee and Sturgess (2001) also found that the most decayed CWD had the greatest species numbers.

Understory diversity (Simpson's D and Shannon's H) and evenness (Pielou's J) during CWD decomposition at Cummins Creek steadily increase while richness peaks and declines (Table 5). These trends differed from those reported for a boreal forest (Kushnevskaya et al. 2007) where Shannon's H and Pielou's J index values declined in the later stages of micro-succession. These differences may suggest more successful niche differentiation among species at Cummins Creek. Direct comparison of indices is hindered with the inclusion of individual lichen and bryophyte species by Kushnevskaya et al. (2007) and by characteristic differences across forest types.

Similar to other succession pathways, those occurring on CWD are governed by site and species availability (Egler 1954; Pickett and McDonnell 1989), substrate variability and microtopographic variation in environmental variables (Beatty 1984; Pabst and Spies 2001), facilitative and inhibitive species interactions (Clements 1916; Connell and Slatyer 1977; Harmon 1989), the timing, severity, and spatial distribution of wind disturbance (Sousa 1984; Pickett and White 1985), and the life history attributes of individual species (Tilman 1985; Halpern 1989). My 
results suggest that CWD substrates support distinct micro-succession pathways from the surrounding forest floor. These findings are also consistent with the intermediate disturbance hypothesis, where moderate levels of disturbance resulting from uprooting or windsnap increase biodiversity by increasing the number of succession pathways within a forest (Savage et al. 2000). Further research is necessary to investigate the effects of each of these factors if we are to better understand the ecological role of CWD in shaping coastal forest succession. 


\section{CONCLUSIONS}

Few studies have investigated the relationship between CWD and understory plant distributions, diversity, and succession in PNW forests. This research addresses that gap by demonstrating CWD increases localscale richness by supporting distinct assemblages of understory communities and influencing understory plant succession. My results further suggest that the availability of CWD substrates may influence understory diversity commensurate with forest canopy structure (e.g., gaps) and geomorphic features in coastal, old-growth PNW forests.

My original hypotheses and specific findings are as follows (Figure 18). First, CWD and mineral soil substrates support distinctly different understory communities. Second, the diversity of each substrate community is similar. Third, community composition on CWD varies over time consistent with log decay. Fourth, CWD community diversity may increase over time. My results failed to show evidence of CWD and forest floor community convergence over time as logs decayed.

More generally, my results indicate that CWD is a primary factor contributing to understory plant diversity and succession in winddisturbed coastal forests and that CWD appears to influence community diversity in coastal forests over longer time scales than what has been 


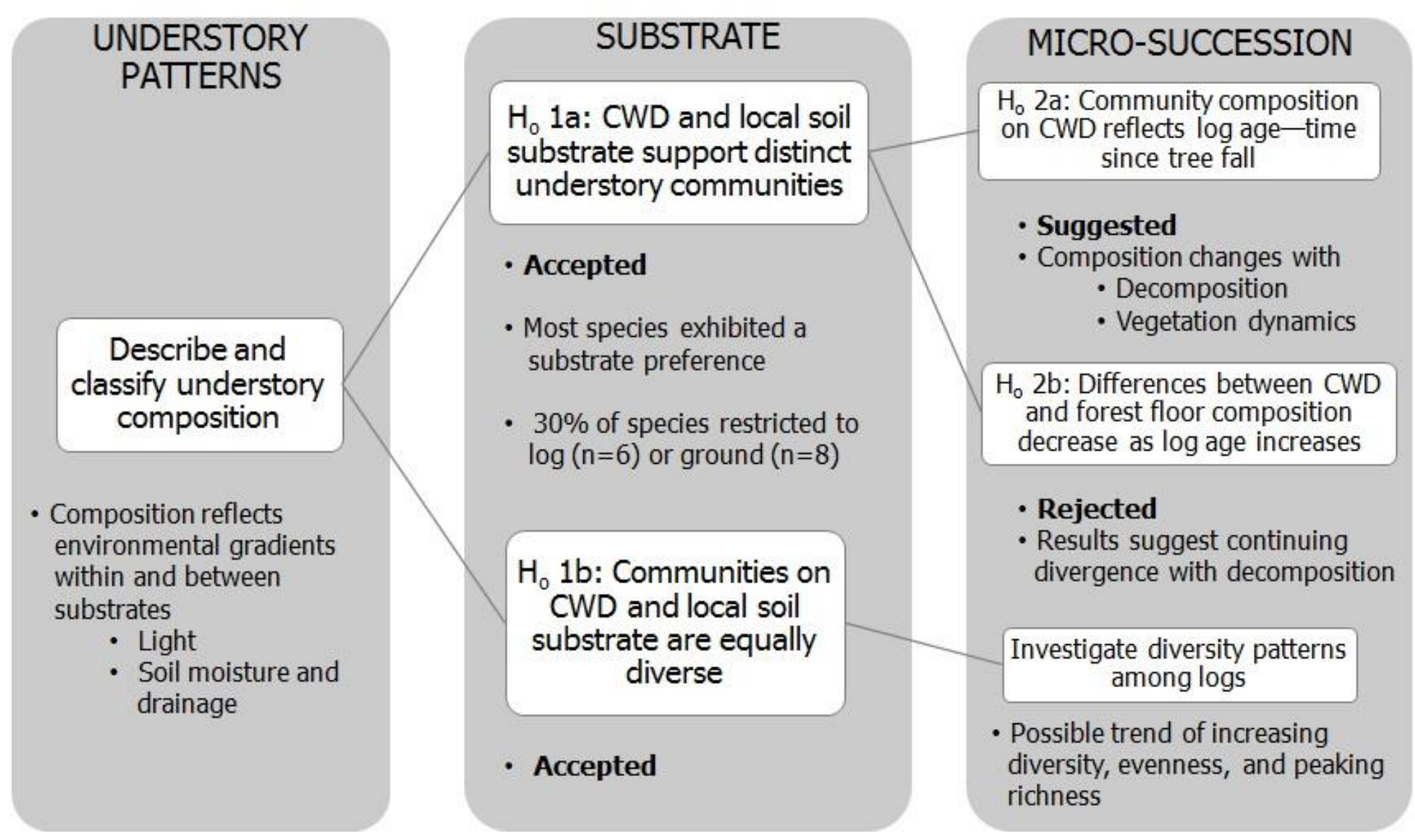

Figure 18. Summary of hypotheses and research outcomes. 
demonstrated in other forest types. These general results are consistent with Connell's (1979) intermediate disturbance hypothesis and represent an incremental contribution toward a broader understanding of species diversity in old-growth, PNW Sitka spruce forests and a basis for improving ecologically sound silvicultural practices.

These findings, while insightful, are provisional because of small sample sizes, absence of direct environmental measurements, and lack of suitable comparators. Future research recommendations include the incorporation of larger sample sizes between substrates and across log decomposition classes. These data should also be collected in conjunction with direct measurements of light and substrate moisture.

This study lacks suitable comparators as the influence of CWD on vascular plant composition is better-documented in deciduous than coniferous forests (Table 1). Previous research in the Sitka sprucewestern hemlock zone has focused on seedling establishment on CWD. In the PNW, understory composition on CWD has only been examined within harvested stands (i.e., Kennedy and Quinn 2001; Six and Halpern 2008). CWD importance may vary with climate, land-use history, and disturbance regime. Additional PNW-based research is needed to clarify the relationships between CWD and understory composition across a wider range of temporal and spatial scales. 


\section{REFERENCES}

Agee, J.K. and M.H. Huff. 1987. Fuel succession in a western hemlock/Douglas-fir forest. Canadian Journal of Forest Research 17:697-704.

Alaback, P.B. 1982. Dynamics of understory biomass in Sitka sprucewestern hemlock forests of southeast Alaska. Ecology 1932-1948.

Alaback, P.B. and F.R. Herman. 1988. Long-term response of understory vegetation to stand density in Picea-Tsuga forests. Canadian Journal of Forest Research 18:1522-1530.

Bailey, J.D., Mayrsohn, C., Doescher, P.S., St Pierre, E., and J.C. Tappeiner. 1998. Understory vegetation in old and young Douglasfir forests of western Oregon. Forest Ecology and Management 112:289-302.

Beatty, S.W. 1984. Influence of microtopography and canopy species on spatial patterns of forest understory plants. Ecology 56:14061419.

Beatty, S.W. and E.L. Stone. 1985. The variety of soil microsites created by tree falls. Canadian Journal of Forest Research 16:539-548.

Beese, W.J., Dunsworth, B.G., Zielke, K., and B. Bancroft. 2003. Maintaining attributes of old-growth forests in coastal BC through variable retention. The Forestry Chronicle 79:570-578.

Boose, E.R., Foster, D.R., and M. Fluet. 1994. Hurricane impacts to tropical and temperate forest landscapes. Ecological Monographs 64:369-400.

Bormann B.T., Spaltenstein, H., McClellan, M.H., Ugolini, F.C., Cromack Jr., K., and S.M. Nay. 1995. Rapid soil development after windthrow disturbance in pristine forests. Journal of Ecology 83:747-757.

Bratton, S. P. 1976. Resource division in an understory herb community: responses to temporal and microtopographic gradients. The American Naturalist 110:679-693. 
Bunnel, F.L., Houde, I., Johnston, B., and E. Wind. 2002. How dead trees sustain live organisms in western forests. USDA Forest Service, General Technical Report PSW-GTR-181.

Christy, E.J. and R.N. Mack. 1984. Variation in demography of juvenile Tsuga heterophylla across the substratum mosaic. Journal of Ecology 72:75-91.

Clarke, K.R. 1993. Non-parametric multivariate analyses of changes in community structure. Australian Journal of Ecology 18:117-143.

Clements, F.E. 1916. Plant succession: an analysis of the development of vegetation. No. 242. Carnegie Institution of Washington.

Connell, J.H. 1978. Diversity in tropical rainforests and coral reefs. Science 199:1302-1310.

Connell, J.H. and R.O. Slatyer. 1977. Mechanisms of succession in natural communities and their role in community stability and organization. American Naturalist 111:1119-1144.

Crawford, R.H., Li, C.Y., and M. Floyd. 1997. Nitrogen fixation in rootcolonized large woody residue of Oregon coastal forests. Forest Ecology and Management 92:229-234.

De Long, S.C., Daniels, L.D., Heemskerk, B., and K.O. Storaunet. 2005. Temporal development of decaying log habitats in wet spruce-fir stands in east-central British Columbia. Canadian Journal of Forest Research 35:2841-2850.

Edman, M., Jonsson, M., and B.G. Jonsson. 2007. Fungi and wind strongly influence the temporal availability of logs in an old-growth spruce forest. Ecological Applications 14:893-901.

Edmonds, R. L. 1991. Organic matter decomposition in western United States forests. In: Proc. Management and Productivity of Western Montane Forest Soils. Edited by Harvey, A.E. and L.F. Neuenschwander. USDA Forest Service Gen. Tech. Rep. INT280:116-128.

Egler, F.E. 1954. Vegetation science concepts I. Initial floristic composition, a factor in old-field vegetation development. Plant Ecology 4:412-417. 
Elzinga, C., Salzer, D., and J. Willoughby. 1998. Measuring and monitoring plant populations. Tech. Ref. 1730-1. Denver, CO: U.S. Department of the Interior, Bureau of Land Management, National Applied Resource Sciences Center. 477 p.

Everham III, E.M. and N.V.L. Brokaw. 1996. Forest damage and recovery from catastrophic wind. The Botanical Review 62:113-185.

Falinski, J.B. 1978. Uprooted trees, their distribution and influence in the primeval forest biotope. Vegetatio 38:175-183.

Fonda, R.W. 1974. Forest succession in relation to river terrace development in Olympic National Park, Washington. Ecology 55:927-942.

Franklin, J.F. and C.T. Dyrness. 1988. Natural vegetation of Oregon and Washington. Oregon State University Press, Corvallis, OR. 464 p.

Franklin, J.F. and C.B. Halpern. 1999. Pacific Northwest forests. In: M. G. Barbour and W.D. Billings, eds. North American Terrestrial Vegetation (second edition). Cambridge University Press, New York: 123-159.

Franklin, J.F., Mitchell, R.J., and B.J. Patrick. 2007. Natural disturbance and stand development principles for ecological forestry. USDA Forest Service, General Technical Report NRS-GTR19.

Franklin, J.F., Spies, T.A., Pelt, R.V., Carey, A.B., Thornburgh, D.A., Berg, D.R., Lidenmayer, D.B., Harmon, M.E., Keeton, W.S., Shaw, D.C., Bible, K., and J. Chen. 2002. Disturbances and structural development of natural forest ecosystems with silvicultural implications, using Douglas-fir forests as an example. Forest Ecology and Management 155:399-423.

Franklin, J.F. and R. Van Pelt. 2004. Spatial aspects of structural complexity in old-growth forests. Journal of Forestry 102:22-28.

Frego, K.A. 2007. Bryophytes as potential indicators of forest integrity. Forest Ecology and Management 242:65-75.

Greene, S.E., P.A. Harcombe, M.E. Harmon, and G. Spycher. 1992. Patterns of growth, mortality and biomass change in a coastal Picea sitchensis-Tsuga heterophylla forest. Journal of Vegetation Science 3:697-706. 
Grier, C. 1978. A Tsuga heterophylla-Picea sitchensis ecosystem of coastal Oregon: decomposition and nutrient balances of fallen logs. Canadian Journal of Forest Research 8:198-206.

Hadley, K.S. and P.A. Knapp. 2011. Detection of high-wind events using tree-ring data. Canadian Journal of Forest Research 41:1121-1129.

Hadley, K.S. and P.A. Knapp. Submitted. Wind disturbance, autecology, and habitat segregation of Sitka spruce and Douglas-fir in Pacific Northwest coastal forests, USA. Journal of Biogeography.

Halpern, C.B. 1988. Early successional pathways and the resistance and resilience of forest communities. Ecology 69:1703-1715.

Halpern, C.B. 1989. Early successional patterns of forest species: interactions of life history traits and disturbance. Ecology 70:704-720.

Hanley, T.A. and W.W. Brady. 1997. Understory species composition and production in old-growth western hemlock-Sitka spruce forests of southeastern Alaska. Canadian Journal of Botany 75:574-580.

Hansen, A.J., Spies, T.A., Swanson, F.J., and J.L. Ohman. 1991. Conserving biodiversity in managed forests. BioScience 41:382392.

Harmon, M.E. 1986. Logs as sites of tree regeneration in Picea-sitchensisTsuga heterophylla forests of coastal Washington and Oregon. Ph.D. Dissertation, Oregon State University, Corvallis, OR. 183 p.

Harmon, M.E. 1987. The influence of litter and humus accumulations and canopy openness on Picea sitchensis (Bong.) Carr. And Tsuga heterophylla (Raf.) Sarg. seedlings growing on logs. Canadian Journal of Forest Research 17:1475-1479.

Harmon, M.E. 1989. Effects of bark fragmentation on plant succession on conifer logs in the Picea-Tsuga forest of Olympic National Park, Washington. American Midland Naturalist 121:112-124.

Harmon, M.E. and J.F. Franklin. 1989. Tree seedlings on logs in PiceaTsuga forests of Oregon and Washington. Ecology 70:48-59. 
Harmon, M.E., Franklin, J.F., Swanson, F.J., Gregory, S.V., Lattin, J.D., Anderson, N.H., Cline, S.P., Aumen, N.G., Sedell, J.R., Lienkaemper, G.W., Cromack Jr., K., and K.W. Cummins. 1986. Ecology of coarse woody debris in temperate ecosystems. Advances in Ecological Research 15:133-302.

Harmon, M.E. and C. Hua. 1991. Coarse woody debris dynamics in two old-growth ecosystems. Bioscience 41:604-610.

Harmon, M.E. and J. Sexton. 1995. Water balance of conifer logs in early stages of decomposition. Plant and Soil 172:141-152.

Houssard, C., Escarre, J., and F. Romane. 1980. Development of species diversity in some Mediterranean plant communities. Vegetatio 43: 59-72.

Huston, M. and T. Smith. 1987. Plant succession: life history and competition. American Naturalist 130:168-198.

Impara, P.C. 1997. Spatial and temporal patterns of fire in the forests of the central Oregon Coast Range. Ph.D. Dissertation, Oregon State University, Corvallis, OR. 354 p.

Kennedy, P.G. and T. Quinn. 2001. Understory plant establishment on old-growth stumps and the forest floor in western Washington. Forest Ecology and Management 154:193-200.

Knapp, P.A. and Hadley, K.S. 2012. A 300-year history of Pacific Northwest windstorms inferred from tree rings. Global and Planetary Change 92-93:257-266.

Kushnevskaya, H., Mirin, D., and E. Shorohova. 2007. Patterns of epixylic vegetation on spruce logs in late-successional boreal forests. Forest Ecology and Management 250:25-33.

Lee, P. and K. Sturgess. 2001. The effects of logs, stumps, and root throws on understory communities within 28-year-old aspendominated boreal forests. Canadian Journal of Botany 79:905-916. 
Lee, P. and K. Sturgess. 2002. Assemblages of vascular plants on logs and stumps within 28-year-old aspen-dominated boreal forests. In: Proceedings of the Symposium on the Ecology and Management of Dead Wood in Western Forests. Edited by Laudenslayer Jr., W.F., Shea, P.J.,Valentine, B.E., Weatherspoon, C.P., and T.E. Lisle. USDA Forest Service Report. PSW-GTR-181:369-380.

Lertzman, K.P., Sutherland, G.D., Inselberg, A., and S.C. Saunders. 1996. Canopy gaps and the landscape mosaic in a coastal, temperate rainforest. Ecology 77:1254-1270.

Lindenmayer, D.B., Franklin, J.F., and J. Fischer. 2006. General management principles and a checklist of strategies to guide forest biodiversity conservation. Biological Conservation 131:433-445.

Lutz, H.J. 1940. Disturbance of forest soils resulting from the uprooting of trees. Yale University: School of Forestry, Bulletin Number 45.

Maechler, M., Rousseeuw, P., Struyf, A., Hubert, M., and K. Hornik. 2012. Cluster: Cluster Analysis Basics and Extensions. R package version 1.14.3.

Maser, C., Tarrant, R.F., Trappe, J.M., and J.F. Franklin. 1988. From the forest to the sea: a story of fallen trees. USDA Forest Service, General Technical Report PNW-229.

Maser, C. and J.M. Trappe. 1984. The seen and unseen world of the fallen tree. USDA Forest Service, General Technical Report PNW164.

McCullough, H.A. 1948. Plant succession on decaying logs in a virgin spruce-fir forest. Ecology 29:508-513.

McCune, B., Grace, J. B., and D.L. Urban. 2002. Analysis of Ecological Communities 28. Gleneden Beach, Oregon: MjM Software Design.

McGee, G. 2001. Stand-level effects on the role of decaying logs as vascular plant habitat in Adirondack northern hardwood forests. Journal of the Torrey Botanical Society 128:370-380.

Miles, J. 1978. Vegetation Dynamics. Chapman and Hall: London. 80 p. 
Minore, D. 1979. Comparative autecological characteristics of northwestern tree species- a literature review. Gen. Tech. Rep. PNW-87. Portland, OR: USDA, Forest Service, Pacific Northwest Forest and Range Experiment Station. 72 p.

Nakashizuka, T. 1989. Role of uprooting in composition and dynamics of an old-growth forest in Japan. Ecology:1273-1278.

Nierenberg, T.R. and D.E. Hibbs. 2000. A characterization of unmanaged riparian areas in the central coast range of western Oregon. Forest Ecology and Management 129:195-206.

Ohmann, J.L. and K.L. Waddell. 2002. Regional patterns of dead wood in forested habitats of Oregon and Washington. In: Proceedings of the Symposium on the Ecology and Management of Dead Wood in Western Forests. Edited by Laudenslayer Jr., W.F., Shea, P.J., Valentine, B.E., Weatherspoon, C.P., and T.E. Lisle. USDA Forest Service Report. PSW-GTR-181:535-560.

Oksanen, J. 2007. Multivariate Analysis of Ecological Communities in R: Vegan Tutorial. 39 p.

URL: $\underline{\text { http://cc.oulu.fi/ jarioksa/opetus/metodi/vegantutor.pdf }}$ Accessed 6/10/2012.

Pabst, R.J. and T.A. Spies. 1998. Distribution of herbs and shrubs in relation to landform and canopy cover in riparian forests of coastal Oregon. Canadian Journal of Botany 76:298-315.

Pabst, R.J. and T.A. Spies. 2001. Ten years of vegetation succession on a debris-flow deposit in Oregon. JAWRA Journal of the American Water Resources Association 37:1693-1708.

Patching, W.R. 1981. Soil Survey for Lane County Area, Oregon. USDA, Soil Conservation Service. U.S. Government Printing Office. 369 p.

Peterson, C.J. and J.E. Campbell. 1993. Microsite differences and temporal change in plant communities of treefall pits and mounds in an old-growth forest. Bulletin of the Torrey Botanical Club 120:451-460.

Peterson, C.J., Carson, W.P., McCarthy, B.C., and S.T.A. Pickett. 1990. Microsite variation and soil dynamics within newly created pits and mounds. Oikos 58:39-46. 
Pickett, S.T., Collins, S.L., and J.J. Armesto. 1987. Models, mechanisms and pathways of succession. The Botanical Review 53: 335-371.

Pickett, S.T. and M.J. McDonnell. 1989. Changing perspectives in community dynamics: a theory of successional forces. Trends in Ecology and Evolution 4:241-245.

Pickett, S.T.A. and P.S. White, eds. 1985. The Ecology of Natural Disturbance and Patch Dynamics. New York: Academic Press.

Pyle, C. and M.M. Brown. 2002. The effects of microsite (logs versus ground surface) on the presence of forest floor biota in a secondgrowth hardwood forest. In: Proceedings of the Symposium on the Ecology and Management of Dead Wood in Western Forests. Edited by Laudenslayer Jr., W.F., Shea, P.J.,Valentine, B.E., Weatherspoon, C.P., and T.E. Lisle. USDA Forest Service Report. PSW-GTR-181:393-403.

Rambo, T.R. 2001. Decaying logs and habitat heterogeneity: implications for bryophyte diversity in western Oregon forests. Northwest Science 75:250-279.

Rambo, T.R. and P.S. Muir. 1998a. Forest floor bryophytes of Pseudotsuga menziesii-Tsuga heterophylla stands in Oregon: influences of substrate and overstory. Bryologist 101:116-130.

Rambo, T.R. and P.S. Muir. 1998b. Bryophyte species associations with coarse woody debris and stand ages in Oregon. Bryologist 101: 366-376.

Rousseeuw, P.J. and L. Kaufman. 1990. Finding groups in data: an introduction to cluster analysis. John, John Wiley \& Sons.

Ruth, R.H. and A.S. Harris. 1979. Management of western hemlock-Sitka spruce forests for timber production. Gen. Tech. Rep. PNW-88. Portland, OR: USDA, Pacific Northwest Forest and Range Experiment Station. 197 p.

Ruth, R.H. and R.A. Yoder. 1953. Reducing wind damage in the forests of the Oregon Coast Range. Research Paper 7. Portland, OR: USDA, Forest Service, Pacific Northwest Forest and Range Experiment Station. 30 p. 
Savage, M., Sawhill, B., and M. Askenazi. 2000. Community dynamics: What happens when we rerun the tape? Journal of Theoretical Biology 205:515-526.

Schaetzl, R.J., Burns, S.F., Johnson, D.L., and T.W. Small. 1989. Tree uprooting: review of impacts on forest ecology. Vegetatio 79:165176.

Schaetzl, R.J., Burns, S.F., Small, T.W., and D.L. Johnson. 1990. Tree uprooting: review of types and patterns of soil disturbance. Physical Geography 11:277:291.

Sharpe, G.W. 1956. A Taxonomical-ecological Study of Vegetation by Habitat in Eight Forest Types of the Olympic Rainforest, Olympic National Park, Washington. Ph.D. Dissertation, University of Washington, Seattle, WA. 313 p.

Six, L.J. and C.B. Halpern. 2008. Substrate effects on distribution, biomass allocation, and morphology of forest understory plants. Botany 86:1133-1142.

Sollins, P. 1982. Input and decay of coarse woody debris in coniferous stands in western Oregon and Washington. Canadian Journal of Forest Research 12:18-28.

Sousa, W. P. 1984. The role of disturbance in natural communities. Annual Review of Ecology and Systematics 15:353-391.

Spears, J.D.H., Holub, S.M., Harmon, M.E., and K. Lajtha. 2003. The influence of decomposing logs on soil biology and nutrient cycling in an old-growth mixed coniferous forest in Oregon, U.S.A. Canadian Journal of Forest Research 33:2193-2201.

Spies, T.A., Franklin, J.F., and T.B. Thomas. 1988. Coarse woody debris in Douglas-fir forests of western Oregon and Washington. Ecology 69:1689-1702.

Stephens, E.P. 1956. The uprooting of trees: a forest process. Soil Science Society Proceedings 20:113-116.

Stewart, G. H. 1988. The influence of canopy cover on understorey development in forests of the western Cascade Range, Oregon, USA. Vegetatio 76:79-88. 
Suchar, V.A. and N.L. Crookston. 2010. Understory cover and biomass indices predictions for forest ecosystems of the Northwestern United States. Ecological Indicators 10:602-609.

Swanson, F.J. and J.F. Franklin. 1992. New forestry principles from ecosystem analysis of Pacific Northwest forests. Ecological Applications 2:262-274.

Taylor, A.H. 1990. Disturbance and persistence of Sitka spruce (Picea sitchensis (Bong) Carr.) in coastal forests of the Pacific Northwest, North America. Journal of Biogeography 17:47-58.

Thompson, J. 1980. Treefalls and colonization patterns of temperate forest herbs. American Midland Naturalist 104:176-184.

Tilman, D. 1985. The resource-ratio hypothesis of plant succession. American Naturalist 125:827-852.

Ulanova, N.G. 2000. The effects of windthrow on forests at different spatial scales: a review. Forest Ecology and Management 135:155167.

USFS. 2013. Cummins Creek Wilderness. Siuslaw National Forest. URL: http://www.fs.usda.gov/recarea/siuslaw/recreation/recarea/?reci $\mathrm{d}=42389$ Accessed 2/20/13.

Van Pelt, R. and J.F. Franklin. 2000. Influence of canopy structure on the understory environment in tall, old-growth, conifer forests. Canadian Journal of Forest Research 30:1231-1245.

Veblen, T.T., Donoso, C., Kitzberger, T., and A.J. Rebertus. 1996. Ecology of southern Chilean and Argentinean Nothofagus forests. In: The ecology and biogeography of Nothofagus forests. Edited by Veblen, T.T., Hill, R.S., and J. Read. Yale University Press, New Haven, Conn. pp. 293-353.

Waring, R.H. and J.F. Franklin. 1979. Evergreen coniferous forests of the Pacific Northwest. Science 204:1380-1386.

Weber, M.H., Hadley, K.S., Frenzen, P.M., and J.F. Franklin. 2006. Forest development following mudflow deposition, Mount St. Helens, Washington. Canadian Journal of Forest Research 36:437449. 
White, P.S. 1979. Pattern, process, and natural disturbance in vegetation. Botanical Review 45:229-299.

Wimberly, M.C. and T.A. Spies. 2001. Influences of environment and disturbance on forest patterns in coastal oregon watersheds. Ecology 82:1443-1459. 


\section{APPENDIX A}

NMDS bubble plots of the eight most abundant shrub and tree species. The areas of the circles are proportional to the relative percent cover of the species in each plot and color coded by substrate.
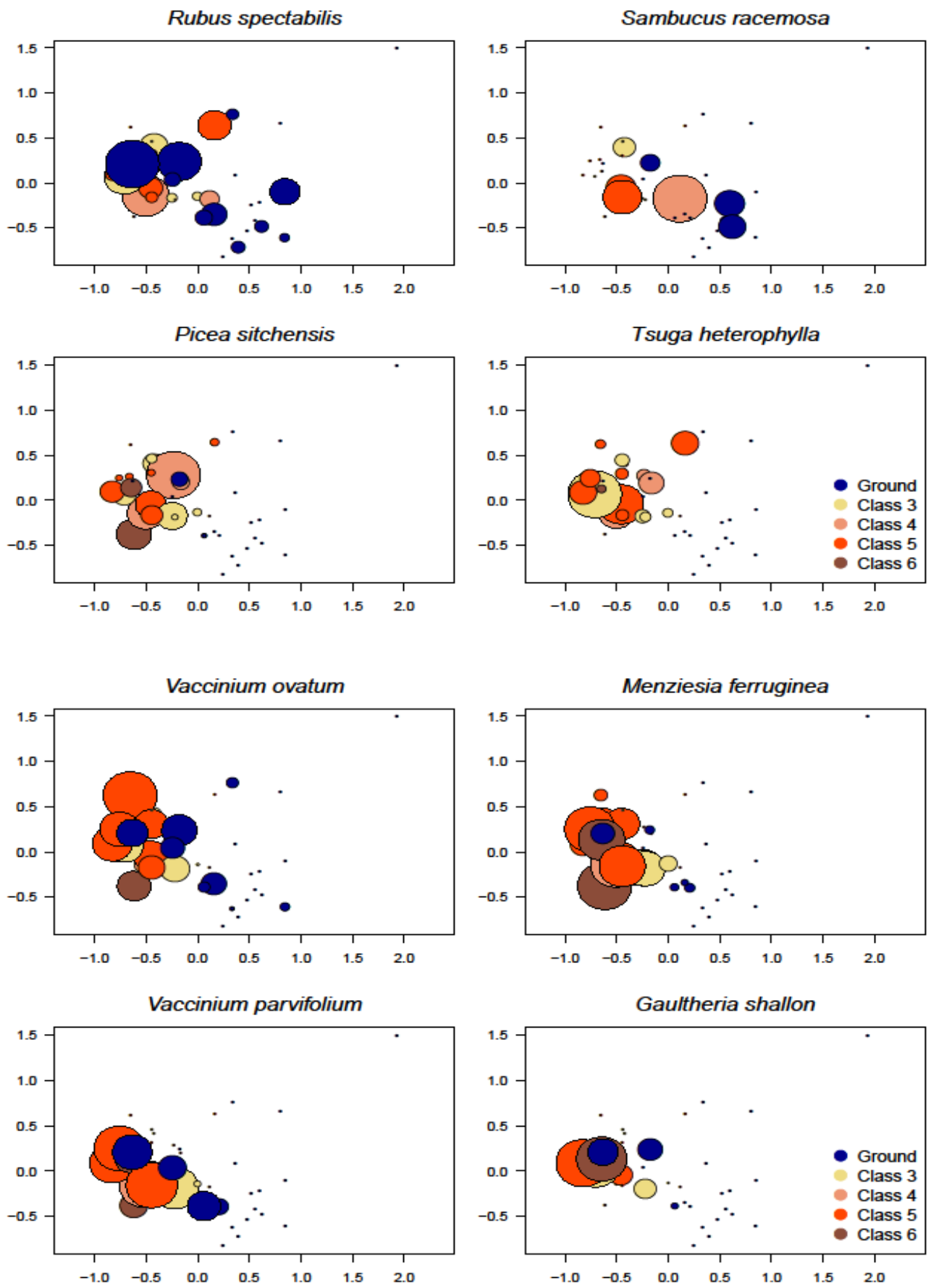
NMDS bubble plots of the six most abundant fern species. The areas of the circles are proportional to the relative percent cover of the species in each plot and color coded by substrate.
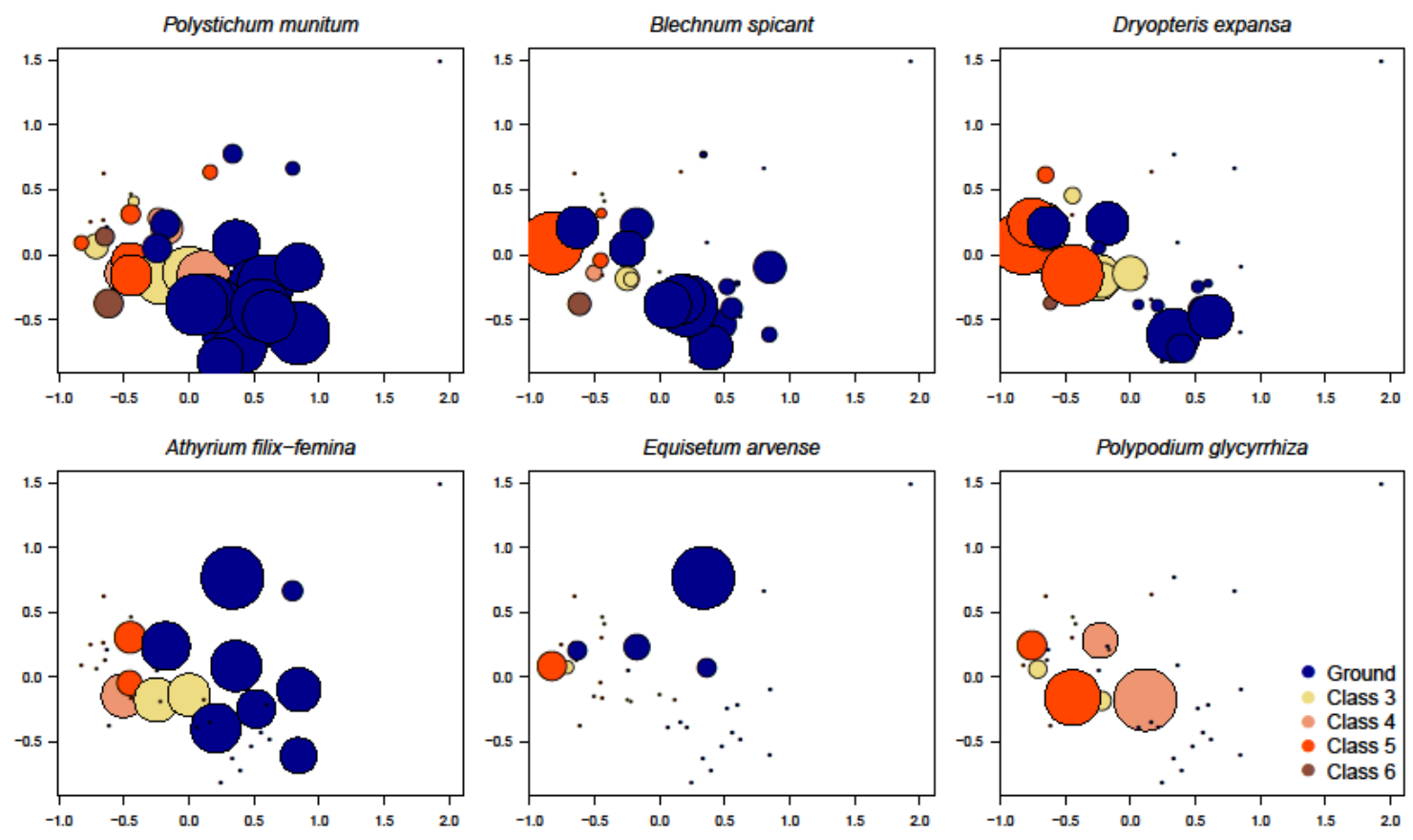
NMDS bubble plots of the 12 most abundant forb species. The areas of the circles are proportional to the relative percent cover of the species in each plot and color coded by substrate.
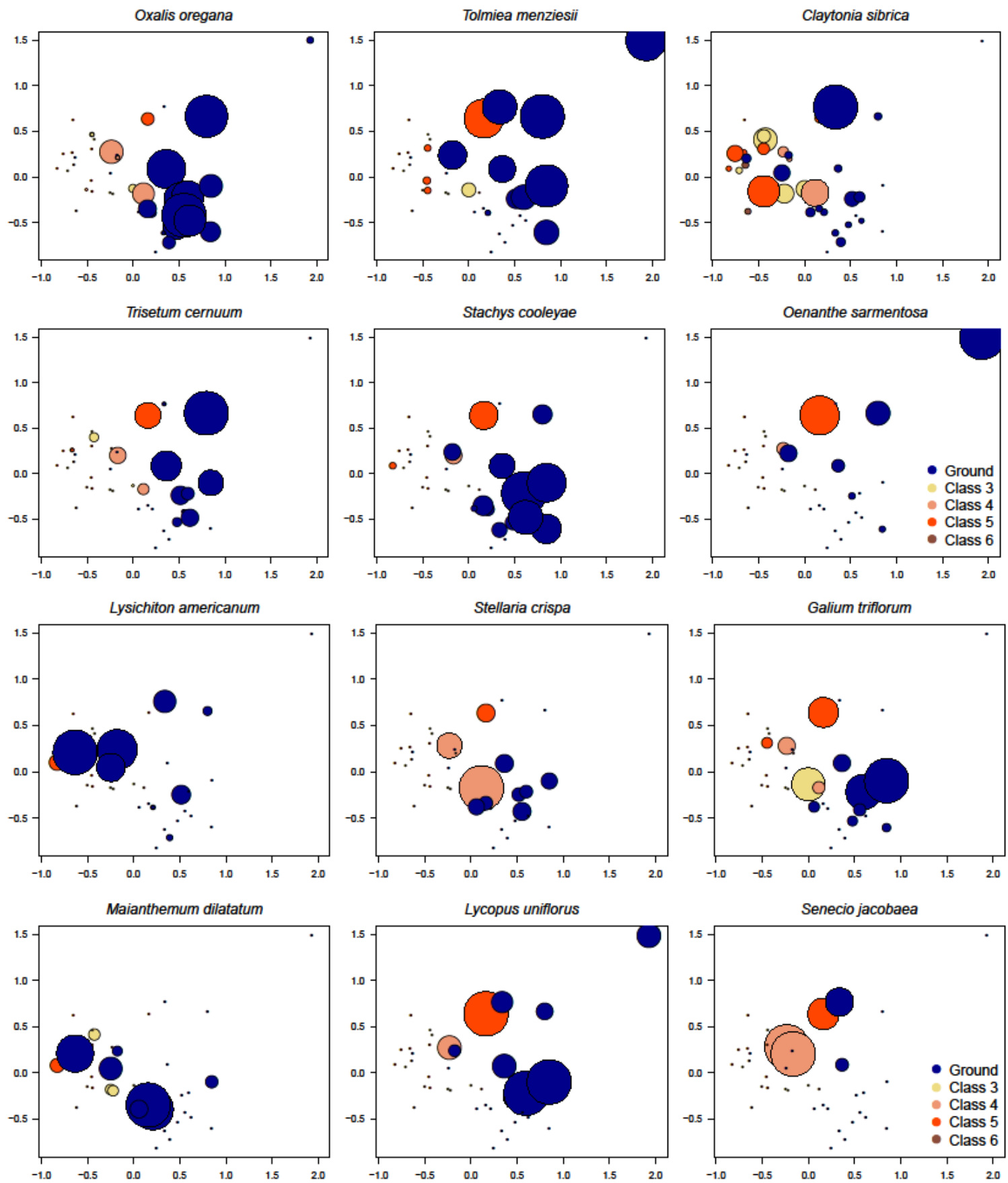